\title{
Market reactions to the implementation of the Banking Union in Europe
}

Livia Pancottoa,", Owain ap Gwilym ${ }^{\mathrm{b}}$ and Jonathan Williams ${ }^{\mathrm{b}}$

${ }^{a}$ Department of Accounting \& Finance, Strathclyde Business School, University of Strathclyde, G4 OQU

${ }^{b}$ Bangor Business School, Bangor University, LL57 2DG, UK

\begin{abstract}
How did announcements about the implementation of the Banking Union (BU) in Europe impact on financial markets? This paper investigates the effect of the overall bank regulatory reform, considering each associated individual announcement, on Credit Default Swaps (CDS), bank stocks and stock futures during 2012-14. Announcements related to the implementation of the supervisory mechanism, as well as those on the new resolution framework, led to a surge in bank CDS spreads, while having a detrimental effect on the wealth of banks' shareholders. The CDS market response to sub-events associated with the ECB's 2014 Comprehensive Assessment (CA) was positive and reflected in a decrease in bank CDS spreads. Furthermore, CDS of Global Systemically Important Banks (G-SIBs) demonstrated a significant reaction to the implementation steps in the BU. Banks' stock prices reacted in a consistent manner with the CDS market. The stock futures market did not reveal any strong reaction to the changes in the European regulatory landscape. Cross-sectional analysis reveals that bank capitalization is positively associated with responses of G-SIBs' CDS spreads, but is inversely related to responses of CDS spreads for other bank groups. Weak underlying credit quality is also a relevant factor in explaining abnormal increases in quoted CDS spreads. For the stock market, positive associations of the cumulative abnormal returns (CARs) with capital levels and with the business model orientation are revealed.
\end{abstract}

Accepted for publication on 21 ${ }^{\text {st }}$ August 2019

\footnotetext{
*Corresponding author. E-mail address: livia.pancotto@strath.ac.uk
} 


\section{Introduction}

"The banking union can only be successful if it delivers an integrated, truly domestic banking market for the euro area" (Enria, 2019)

The European Banking Union (BU) project implies a significant shift of regulatory responsibilities from the national to the European level and represents a substantial step forward in the process of fostering financial integration and weakening the detrimental feedback loop between bank and sovereign risks (Acharya, Drechsler and Schnabl, 2014). The first building block, a common supervisory framework for the banking system, became effective in November 2014, with the European Central Bank (ECB) at the head of the Single Supervisory Mechanism (SSM). The Single Resolution Mechanism (SRM), the second cornerstone, which aims to ensure timely and effective resolution of failing banks, was launched in 2015 and became fully operational in January 2016. ${ }^{1}$ A European Deposit Insurance Scheme (EDIS), the third pillar of the BU, remains a subject of debate at the time of writing. ${ }^{2}$

The transition towards BU started with the 12-month Comprehensive Assessment (CA) of the euro area banking system. This preliminary financial health check consisted of an Asset Quality Review (AQR) and a Stress Test component. The CA was applied to the 130 largest European credit institutions, which account for around $82 \%$ of the total euro area banking assets. The CA commenced in late 2013 and the results were published on 26 October 2014. ${ }^{3}$ Although the CA was mostly considered as a robust and credible exercise, concerns were raised regarding the rigour and impartiality. The ECB was forced to choose between a "rock and a hard place". An overly strict assessment, disclosing large capital shortfalls, could have threatened financial stability. In contrast, an overly lenient exercise could have undermined the ECB's credibility. Moreover, the focus on a single capital ratio, the Common Equity Tier 1 (CET1), represented a weakness. On this point, Steffen (2014) highlights the issues associated with the adoption of regulatory capital ratios, which crucially rely on the assumption that the weights correctly reflect the risk of the underlying asset. Also, the non-recognition of the systemic risk arising from linkages and feedback effects between banks, as well as the exposures to similar assets and comparable macroeconomic shocks, heavily influenced the outcome of the CA.

Acharya and Steffen (2014) provide an alternative benchmark methodology to estimate capital shortfalls of European banks. Building their approach on publicly available market data, they document capital gaps significantly larger than the figures disclosed by the ECB. In their view, the results of the regulatory stress test were heavily influenced by the flexibility of national

\footnotetext{
1 The SRM includes a Single Resolution Board (SRB) and a Single Resolution Fund (SRF) and implements the EU-wide Bank Recovery and Resolution Directive (BRRD) in the euro area.

${ }^{2}$ In November 2015, the European Commission (EC) proposed a EDIS. The gradual creation of such a scheme might imply a temporary "mutualisation" period, through a top-up or reinsurance mechanism, to end in 2024 with a fullyfledged and common EDIS.

3 The CA identified an overall capital shortfall of $€ 24.6 \mathrm{bn}$, across 25 credit institutions. Considering the amount of net capital raised by the participating banks (starting from end-2013), the capital gap which remained to be addressed was $€ 9.5 \mathrm{bn}$, distributed across 13 institutions.
} 
regulators in defining and measuring bank capital and by the reliance on risk-weighted assets. ${ }^{4}$ The differences between their estimations and the official shortfalls, which are mostly driven by large banks in core European countries, i.e. France and Germany, demonstrate the relevance of using alternative capital measures, while limiting political influence. Barucci et al. (2018) confirm that, in the 2014 CA, a standard leverage ratio was better able to capture banks' risk than riskadjusted measures. Also, these authors provide evidence of a difference in the treatment of banks depending on their country of origin, i.e. core versus peripheral countries.

Despite the impressive achievement in the (r)evolution of the European banking regulatory architecture, there are very few papers focusing on the market reaction to the implementation of the BU. Moreover, the prior empirical literature only considers a single step of the overall reform, i.e. the CA. Carboni et al. (2017) document a negative stock market reaction on the CA announcement date and disclosure of its results, while confirming an increased level of transparency arising from the assessment. Their findings also show that, in the short-run, stock prices of banks subject to direct ECB supervision had a more pronounced negative reaction, compared to those maintaining national supervision. Sahin and de Haan (2016), on a univariate basis, report the reaction of financial markets to the CA announcement and the publication of its outcomes. The authors find that banks' stock prices and Credit Default Swap (CDS) spreads did not react to these events. There is some limited evidence of markets' responses only when grouping banks per country. Barucci et al. (2018), whose research questions and methodology differ from ours, provide a thorough analysis of the CA results, while investigating the determinants of banks' capital shortfalls.

Subsequent aspects of the regulatory transition have also received relatively little attention in terms of academic evidence on the financial market responses. The introduction of the BRRD, which is the legal basis of the SRM and is applied to all EU Member States, represented one of the most important regulatory changes in Europe during recent years (Constâncio, 2014). Marking the end of the culture of bail-out and the beginning of the culture of bail-in, the BRRD foresees a minimum set of common rules and procedures for the recovery and resolution of European credit institutions and investment firms. From 2016, all bank resolution cases require a bail-in of shareholders and creditors equal to at least $8 \%$ of the total liabilities of a given bank, including own funds. ${ }^{5}$ Therefore, a bank's investors, not taxpayers, should bear the costs of bank failures. Conlon and Cotter (2014) investigate what might have been the implications of the new European resolution framework, and associated bail-in tool, for euro area banks during the global financial crisis. Their findings indicate that the existence of a bail-in mechanism would have mainly impacted equity and subordinated debt holders of European banks. Depositors would not have

\footnotetext{
${ }^{4}$ A truly consistent definition of capital applied to all the banks supervised by the ECB has been employed since November 2014 when the Supervisory Review and Evaluation Process (SREP) was adopted (Véron, 2015).

5 The ongoing debate on the bail-in of bank liabilities is based around the convergence of two distinct concepts: the Total Loss Absorbing Capacity (TLAC), issued by the Financial Stability Board (FSB) and the Minimum Requirement for Own Funds and Eligible Liabilities (MREL), set in conformity with the BRRD. While both requirements pursue the same overall objectives, they differ in terms of scope and features (Berger et al., 2016).
} 
been involved in any of their analysed cases, limiting the danger of a potential "flight-to-safety" effect and associated risk of contagion. Benczur et al. (2017) explore the effectiveness, in terms of impact on public finance costs, of the new EU post-crisis bank regulatory framework. Based on their empirical exercise, and in a crisis setting similar to the recent one, the introduction of the bail-in mechanism alone results in a reduction in the call for public bail-outs of about $2.3 \%$ of EU GDP.

This paper presents the results of an event study on the impact upon financial markets of the implementation of the BU project. Unlike prior evidence mentioned above, which focused exclusively on the ECB's CA (Sahin and de Haan, 2016; Carboni et al., 2017; Barucci et al., 2018), and therefore a small number of announcements, the analysis conducted in this paper examines the effects of the overall banking reform, inclusive of each intermediate step. By exploiting 17 official ECB announcements, concerning various aspect of the new regulatory architecture, we investigate the impacts on banks' CDS, stocks and stock futures. A further interest lies in the potential heterogeneity in the market reactions across different banks' sub-groups. The crosscountry comparison, which covers institutions that vary both in terms of bank- and countryspecific characteristics, enables the investigation of how banks located in neighbouring yet different banking sectors respond to the introduction of the new rules. Finally, in a multivariate framework, we explore to what extent bank-specific characteristics drive heterogeneous reactions.

Our research can be positioned within the strand of theoretical studies which address the establishment and implementation of the BU (among others, Goyal et al., 2013; Herring, 2013). It complements the prior empirical evidence on the implications of the reform and its specific components (Conlon and Cotter, 2014; Carboni et al., 2017; Barucci et al., 2018) and extends the broader literature that uses event studies to analyse the effects of changes in banking regulation (Horváth and Huizinga, 2015; Schäfer et al., 2016; Bruno et al., 2018). Our work differs from the most closely related studies, i.e. Carboni et al. (2017) and Barucci et al. (2018), by focusing on the entire set of official announcements associated with the BU components, spanning from the launch of the project (i.e. September 2012) to November 2014 when the SSM became effective. ${ }^{6}$ Moreover, in a further key contribution of this paper, we address the responses of three different financial markets and account for various types of institutions, headquartered in different countries. Finally, aimed at explaining the potential drivers of the market reactions, we consider linkages between the cross-sectional variation in the Cumulative Abnormal Returns (CARs) and bank-specific characteristics. Revealing the financial market responses to the establishment of the various regulatory mechanisms is an essential element to gain an appreciation of the level of credibility of the new institutional framework. Credibility and trust are necessary preconditions to the

\footnotetext{
${ }^{6}$ Carboni et al. (2017) focus on only nine events, all of them exclusively related to the CA. By including two further official announcements on the CA (i.e. 08/08/14 "ECB publishes Comprehensive Assessment Stress Test Manual" and 04/09/14 "ECB publishes final list of significant credit institutions"), as well as all of those on the supervisory and resolution mechanisms, we extend and complete the list of key dates on the BU. Barucci et al. (2018) employ a different empirical methodology and have a narrow interest in the disclosure of the CA results only.
} 
realisation of the vision of a complete and effective BU, which ensures the safeness of depositors' funds and prevents the use of taxpayers' money to foot the bill for bank failures (Gehrig et al., 2016; Angeloni, 2019).

We briefly preview the main findings. The univariate analysis demonstrates that the CDS and the stock markets responded in a broadly consistent manner to the information content related to BU news releases. The implementation of the supervisory element of the new EU institutional framework leads to a surge in bank CDS spreads, while having a detrimental effect on stock prices. The CDS market response to the announcements on the CA has been positive, meaning that CDS spreads for all the bank groups decreased. Announcements about the new bank resolution regime induce higher CDS spreads, which can be attributed to the forthcoming bail-in rules. In the stock market, the reaction to events related to the $\mathrm{CA}$ is positive and pronounced for the majority of the bank groups, having a similar underlying implication as the evidence found for the CDS market. The impact of the announcements about the new bank resolution rules is negative on all banks' stocks, but more limited compared to the CDS market. Findings for the stock futures market do not highlight any systemic pattern of reactions to the implementation of the new BU architecture. This potentially reflects a stronger presence of well-informed participants in the derivatives market.

The cross-sectional analysis reveals that the level of bank capitalization is positively associated with responses of G-SIB's CDS spreads, but has a negative link with responses of CDS spreads for other bank groups. For banks located in non-euro area countries and the G-SIBs, weak underlying credit quality is a relevant factor in explaining abnormal increases in CDS premia. Bank size does not alter the market participants' perception of bank riskiness. For the stock market, a higher level of capitalization is associated with positive abnormal reactions. Similar evidence holds for the stock prices of institutions which are more oriented to traditional lending activities.

The remainder of the paper is organized as follows. Section 2 outlines the hypotheses. Section 3 describes the data and methodology. Section 4 discusses the multivariate analysis. Section 5 reports the empirical results. Section 6 provides some robustness checks and Section 7 concludes the paper. 


\section{Hypotheses}

\subsection{CDS market reaction}

Establishing a prior hypothesis for the anticipated direction of the CDS market reaction to the new regulatory regime is relatively straightforward compared to the stock and stock futures markets. The general aim of the BU project of strengthening the euro-area banking sector might be perceived to reduce bank riskiness. The redistribution of the risk between taxpayers, depositors and creditors, as a result of the new bail-in rules, together with an enhanced market discipline might also contribute to a reduction of the overall risk in the system. ${ }^{7}$ Thanks to the bail-in powers and to an increased transparency, funding costs would better reflect the banking risk improving the overall financial stability (Dell'Ariccia et al., 2018). Therefore, a decrease in banks' CDS spreads would be expected, given their inherent nature as risk indicators.

The bail-in mechanism for dealing with ailing banks, which refers to the re-capitalization of the institutions via the compulsory write-down of liabilities or the conversion of debt into equity, is an underlying feature of both the BRRD and the SRM (Conlon and Cotter, 2014). The bail-in basis spans from junior to senior unsecured debt, also including uninsured customer deposits which exceed €100,000. When considering this new bail-in philosophy, a reduction in bail-out expectations across banks would be expected with a consequent increase in credit risk premia. This would be in turn reflected in a rise in CDS spreads, linked to an increased perception of banking default risk. ${ }^{8}$ This evidence contrasts with the pre bail-in period (especially during 200809), when bank bailouts were associated with decreasing bank CDS spreads (Ejsing and Lemke, 2011).

Furthermore, different types of banks, as well as banks located in different countries, might show different price reactions to the selected announcements. G-SIBs, for instance, are expected to experience a larger reduction in bailout expectations and, thus, a more pronounced CDS market reaction than smaller banks for events associated with the new resolution regime. The new bail-in rules should in principle affect more those institutions that in the past would have most benefited from an implicit public subsidy (Leonello, 2018). Also, within this category, it should impact the riskiest banks the most. A similar consideration would hold for banks located in peripheral euro area countries, particularly affected by the sovereign debt crisis and with high levels of public debt. As naturally in a different position compared to their peers, market reactions of banks located outside the euro area are expected to be less strong than those of banks situated in euro area economies.

\footnotetext{
7 The removal of implicit guarantees should increase the effort of debt-holders in monitoring banks, therefore mitigating moral hazard issues. This, in turn, should reduce the CDS spreads (IMF, 2014).

${ }^{8}$ As a consequence of the increased level of risk, holders of bail-in liabilities might be expected to require a higher return, all else being equal.
} 


\subsection{Stock and stock futures market reactions}

Stigler (1971) proposes that regulatory reforms provide opportunities to expropriate wealth from competitor groups ("capture theory"). Another prominent viewpoint, the "publicinterest" hypothesis, is that regulation serves the public interest to enhance social welfare at the expense of the regulated industry (Needham, 1983). ${ }^{9}$ It is plausible to conceive how this paper's analysis would fit under this viewpoint i.e. increasing the stability and the solvency of the European banking system would serve the public interest.

Influential work by Schwert (1981) argues that investors seek to identify regulation that might lead to increased asset prices while discouraging regulation that decreases asset prices. Therefore, they tend to sell the stocks of firms for which regulatory changes are detrimental and buy the stocks of firms that might benefit from these changes. In this sense, expectations are fundamental and play a crucial role in influencing investors' decisions. Changes in regulation might lead investors to modify their beliefs about expected returns, thereby affecting their propensity to hold stocks, e.g. bank equity in the context of this paper. In the worst scenario, this could result into a general investors' aversion towards funding banks and this might have consequent systemic repercussions (Bruno et al., 2018).

The overall impact of the implementation of BU on bank shareholders is not clear a priori. An appreciation in stock prices might be expected if the new regulatory framework is perceived as influential in improving banks' stability without having excessive negative impacts on their profitability. By lowering potential systemic risk and contagion (a notable feature of the European sovereign debt crisis), the new regulation might entail positive shareholder wealth effects. Moreover, stock prices might also react positively due to the perceived benefits of a convergence towards a common set of rules applied at European level (i.e. "level playing field").

When considering the ECB's CA, which represented the entry point to the first pillar of BU (i.e. the SSM), a potential adverse market reaction might be anticipated due to the impact of the procedure on the banking sector's profitability. In this regard, additional capital associated with extra provisioning, as a consequence of the asset re-evaluation, might be expected to negatively impact banks' ROE and their stock prices (Schäfer et al., 2016). The underlying assumption would be that equity capital for banks is perceived to be more expensive than debt, due to the tax deductibility of interest and the presence of implicit subsidies (Moenninghoff et al., 2015). Under this view, because of the potential increase in funding costs, the impact would be expected to be stronger for both the group of G-SIBs and that of credit institutions located in euro area peripheral countries (GIIPS countries). Additionally, more stringent but still not completely transparent new rules on failing banks, could lead to a potential negative reaction in the stock market. ${ }^{10}$ Finally,

\footnotetext{
${ }_{9}^{9}$ When unanticipated changes in regulation occur, the capture theory would generally predict positive ARs, while the public interest theory would predict the opposite.

10 Differences in the implementation of the BBRD at national levels, with respect to bail-in hierarchies, might increase uncertainty in the stock market. From this perspective, the 2015 cases of the Portuguese Banco Novo and the four Italian regional banks (i.e. Banca Etruria, Banca Marche, CariFerrara and CariChieti) are significant.
} 
similarly to the CDS market, the market impact on institutions based in non-euro area countries would be expected to be less pronounced than that observed for banks located in the euro area countries. Nevertheless, due to a potential competitive advantage, a neutral or positive market reaction would be expected. Table 1 summarizes, for the CDS, stock and stock futures markets, the stated hypotheses regarding the expected reactions to the selected key announcements related to the BU.

Beyond the analysis of the stock market reaction, it is plausible that different or stronger reactions could be observed in the stock futures market. In perfectly frictionless, complete and rational markets, prices of stocks and their corresponding derivatives would be anticipated to simultaneously incorporate new information. However, a common view in the literature is that derivatives can potentially react differently or more quickly (e.g. Back, 1993). This is attributed to a preference of sophisticated and well-informed participants to trade in derivatives at times of information arrival. This can be induced by leverage in derivatives, alongside funding constraints, transaction costs, short-selling restrictions and constraints on borrowing securities in the stock market (e.g. Black, 1975). While the empirical evidence is mixed, many findings indicate a strong role for stock futures in the price discovery process (e.g. Aggarwal and Thomas, 2019; Jain et al., 2019). In contrast, the activity of informed traders in futures markets could be deterred by noise trader risk during specific periods characterised by sentiment-based factors (e.g. Lin et al., 2018). Therefore, it is a worthwhile empirical exercise for this paper to consider stock futures alongside the stock and CDS markets.

\section{Data and methodology}

\subsection{Sample selection}

The initial sample comprises the European banks subject to the ECB's 2014 CA. After thorough investigation of data sources, the original sample of 130 institutions was reduced due to data availability and other quality and/or liquidity constraints. Specifically, the largest sample, which is for the stock market analysis, includes 50 banks from 19 European countries, comprising those that are publicly listed and with liquid traded stocks. The CDS market analysis is conducted on a sub-sample of 33 credit institutions due to data availability, while the sample for the stock futures includes 24 banks (Table 2). ${ }^{11}$

Daily CDS quotes on senior 5-year debt contracts (with a modified-modified restructuring clause) are employed, because these are the most liquid and are widely adopted in the academic literature (e.g. Horváth and Huizinga, 2015; Schäfer et al., 2016; Sclip et al., 2019). For the stock and stock futures markets, daily closing prices are used. The reference currency is the Euro for all market prices. For institutions located outside the euro area, prices are converted to Euros when

\footnotetext{
11 The applied liquidity criterion, applied for the three markets, was to retain only entities for which returns/spread changes were non-zero in over $50 \%$ of the observations. This led to the exclusion of two Cypriot banks and one bank from Malta. Another four banks (one each from Austria, Germany, Poland and Slovakia, respectively) were also excluded from the analysis, in a previous step, due to data inconsistency.
} 
necessary. Data are obtained from Thomson Reuters Datastream for the period from 1 June 2011 to 30 November 2014. The data spans beyond the time around the considered announcements in order to estimate the expected returns.

The empirical analysis is also conducted on multiple bank sub-groups. Investigating these different sub-samples provides scope to capture the potential heterogeneity of reactions across different groups of banks. The four sub-samples consist of banks which are (i) located in euro area countries ("EU_EZ"); (ii) located in euro area peripheral countries (“GIIPS" countries); (iii) headquartered in European but non-euro area countries ("EU_NONEZ"); (v) classified as G-SIBs.

\subsection{Event dates}

The initial set of event dates is defined by all the ECB's press releases on the BU project for the period spanning from the launch of the project (i.e. autumn 2012) to the starting date of the SSM, i.e. 4 November 2014. Elements of the regulatory reform are revealed over a period of around three years. Therefore, in order to correctly interpret and appreciate the effect of its implementation, it is fundamental to assess the informational content of each associated sub-event. Considering only ECB official announcements (an approach which is consistent with Petrella and Resti, 2013; Carboni et al., 2017 and Bruno et al., 2018) led to the identification of a set of 25 event dates. To better investigate the extent to which these official announcements conveyed relevant information to the financial markets, detailed research on the related media coverage was performed, resulting in the selection of 17 key events. Eight of these events are associated with the CA, seven with the banking supervision component and two with the bank resolution framework. ${ }^{12}$ Finally, a cross-sectional check to rule out the presence of significant confounding events was conducted using LexisNexis. Table 3 reports the relevant event dates included in the analysis.

\subsection{Empirical methodology}

The event study approach is well-designed to investigate the valuation effects of regulatory reforms. We opt for this methodology because the new banking rules are gradually implemented over some years starting from 2012 and an examination of their long-term impact on banks' behaviours would require a much longer time-frame. Combining accounting and market data represents an effective strategy to test how market participants evaluate the newly established mechanisms.

Moreover, the analysis of the impact of changes in regulation by means of event studies has been very widely applied in the banking literature and we highlight some recent examples here. Veronesi and Zingales (2010) investigate the effect of the 2008 Paulson Plan on the value of US banks. Bayazitova and Shivdasani (2012) examine the effects on US financial institutions of the government capital injections under the Troubled Asset Relief Program (TARP). Norden et al. (2013) investigate the impact on stock market performance of corporate borrowers arising from

12 This search was conducted using the online Financial Times-EU edition and the websites of Reuters and Bloomberg. Eight announcements were removed from the original 25 because they were mainly related to the nomination of the Supervisory Board's members and its composition. 
government interventions in the US banking industry during the 2007-financial crisis. Horváth and Huizinga (2015) analyse the reaction in euro area financial markets to the single announcement on the creation of the European Financial Stability Facility (EFSF) in 2010. Moenninghoff et al. (2015) explore the stock price reactions of large banks to the 2009 additional regulation on G-SIBs. Schäfer et al. (2016) investigate the reactions of European and US financial markets to major regulatory reforms during 2009-11. Bruno et al. (2018) evaluate the stock market reactions of European banks to announcements on liquidity regulation under the Basel III framework.

In the first step of the event study, the abnormal return (AR) of a financial asset is estimated as the difference between the actual (ex post) return and the expected (ex ante) return, over the selected event window. ${ }^{13}$ Expected or normal return estimations are obtained through the market model specified as follows:

Equation 1

$$
\begin{gathered}
R_{i, t}=\alpha_{i}+\beta_{i} R_{m, t}+\varepsilon_{i, t} \quad 14 \\
\text { with } \quad E\left[\varepsilon_{i, t}\right]=0 \quad \operatorname{VAR}\left[\varepsilon_{i, t}\right]=\sigma^{2}
\end{gathered}
$$

and where $R_{i, t}$ is the daily asset return of bank $i$ at time $t, R_{m, t}$ is the market return and $\varepsilon_{i, t}$ is the zero mean error term. Market model parameters, i.e. $\alpha_{i}, \beta_{i}$ and $\sigma^{2}$, are estimated by OLS over a 255-day estimation window ending 20 days before the announcement date. For CDS, absolute spread changes (as in Hull et al., 2004 and Norden and Weber, 2004) are calculated, while for stocks and stock futures, log returns are computed. The ITRAXX Europe Senior Financial 5Y Index (sourced from Bloomberg), the STOXX Europe 600 Banks Index and the Eurex Euro STOXX Banks Index Futures (sourced from Datastream) are employed as the proxies for the CDS, stock and stock futures market portfolios, respectively.

The ARs are obtained as the difference between the actual returns and the estimated values, unconditional on the events, predicted by the market model:

\section{Equation 2}

$$
A R_{i, t}=R_{i, t}-\left(\widehat{\alpha}_{\imath}-\hat{\beta}_{i} R_{m, t}\right)
$$

Negative abnormal changes in CDS spreads reflect a decrease in the market's perception of bank riskiness, while positive abnormal CDS spreads imply the reverse. Negative ARs for stock prices and stock futures indicate "abnormal" drops following an event, and vice versa.

The ARs are then aggregated over the relevant event window around the announcement date $t=0$, in order to obtain the Cumulative Abnormal Returns (CARs), and to compute the Cumulative Average Abnormal Returns (CAARs) as the mean of the CAR estimates for each event.

\footnotetext{
${ }^{13}$ ARs relate to the analysis for stock and stock futures markets, whereas abnormal spreads apply for the CDS market. In the remainder of the paper, the terminology for the analysis on the CDS market also refers to ARs.

14 The corresponding measure of the abnormal spread changes in the CDS market is given by the following formula: $\Delta C D S_{i, t}=\alpha_{i}+\beta_{i} \Delta$ Index $_{t}+\varepsilon_{i, t}$. This approach is consistent with e.g. Norden and Weber (2004), Morgan et al. (2014), Sahin and de Haan (2016).
} 
Equation 3

$$
\operatorname{CAR}_{i}\left(t_{1}, t_{2}\right)=\sum_{t=t_{1}}^{t_{2}} A R_{i, t}
$$

Equation 4

$$
\operatorname{CAAR}\left(t_{1}, t_{2}\right)=\frac{1}{N} \sum_{i=1}^{N} \operatorname{CAR}_{i}\left(t_{1}, t_{2}\right)
$$

The focus is on a symmetric 3 -day event window $(-1,+1)$ to capture effects that can potentially occur after the markets close, as well as leakage and lag effects. Employing a short event window mitigates the impact of potentially confounding effects, whose influence usually increases with a wider event window. For robustness, the univariate analysis on the CDS and stock markets is also conducted on a 1-day event window (see Section 6). Finally, to test whether the CAARs significantly differ from zero (i.e. $H_{0}: C A A R=0$ ), both non-parametric and parametric tests are employed to improve the reliability of inferences. To simultaneously account for crosssectional correlation in the residuals and event clustering, the adjusted version of the Boehmer et al. (1991) test, proposed by Kolari and Pynnönen (2010), is employed. As a non-parametric test statistic, the generalized sign test by Cowan (1992) is used, which accounts for the proportional distribution of positive against negative abnormal returns. ${ }^{15}$

\section{Multivariate analysis}

This second aspect of the analysis focuses on the extent to which bank-specific factors could potentially amplify or mitigate the financial market responses to the selected regulatory events. The investigation of the cross-sectional determinants of CARs using a 2-stage approach is common in the banking literature (e.g. Moenninghoff et al., 2015; Carboni et al., 2017; Bruno et al., 2018). ${ }^{16}$ Therefore, in the following multivariate analysis, we employ various bank-level explanatory variables (Table 4) with the aim of explaining any heterogeneity in the bank CARs. ${ }^{17}$

Except for the bank size indicator, which is measured as the natural logarithm of total assets (measured in million Euros), all other variables are ratios. These are constructed from banks' balance sheet information, on an annual basis, obtained from the BankScope database for

\footnotetext{
15 The use of the event study methodology is not without limitations. Identifying the precise event date might represent a challenge, which we have dealt with by selecting only ECB official announcements and employing a 3-day event window centred on the announcement day. This approach also alleviates any prior market anticipation of an information arrival. The use of the adjusted BMP test accounts for potential biases arising from employing the same set of event dates for firms from the same industry. Using a non-parametric significance test provides further robustness to the findings.

${ }^{16}$ As discussed in seminal contributions by MacKinlay (1997) and Binder (1998), the cross-sectional regression approach is a standard practice in the event study methodology and represents an appropriate tool to explore the association between the estimated CARs and firm-specific characteristics. However, we recognise that some limitations exist with this approach. The use of CARs as the dependent variable in the regression approach might raise some concerns in terms of behaviour of the residuals and efficiency of the estimates. However, Karafiath (1994) and McWilliams and Siegel (1997) directly address this matter and they argue that using the OLS estimator with a heteroscedasticity correction is appropriate and any potential benefit of using more complex procedures is modest.

17 In the interests of brevity and due to the similarities between the stock and stock futures markets, we limit the tabulated multivariate results to the CDS and stock markets. Also, the motivation to include the stock futures analysis was based on price discovery and information arrival rather than cross-sectional aspects.
} 
the period 2012-14. The CET1 ratio data are gathered from SNL Financial. Due attention is given to potential multicollinearity among explanatory variables. For this reason, capital explanatory variables (i.e. TIER1_RATIO, CET1 and LEVERAGE_T) are selected separately as alternatives. ${ }^{18}$ Moreover, to deal with the presence of potential outliers, all bank-level explanatory variables, as well as the dependent variable, are winsorized at $1 \%$ in each tail of the distribution (in line with Armour et al., 2017; Bruno et al., 2018 and many others). Table 5 reports the main descriptive statistics on the variables employed in the regression analysis.

\subsection{Can bank-specific features influence financial markets' reactions?}

The immediate reactions of financial markets to the various announcements on the BU, spanning from September 2012 to November 2014, might have been conditioned by differences at the bank level.

In relation to the CDS market, the core function of bank capital in absorbing unexpected losses and preventing potential insolvency should be of primary importance. Well-capitalized banks, with their associated lower probability of default, are expected to demonstrate less evidence of abnormal CDS reactions than those which are less capitalized (Chiaramonte and Casu, 2013; Sclip et al., 2019). Moreover, under-capitalized institutions might have more incentives to adopt excess risk-taking behaviour (Acharya and Steffen, 2015).

Better-capitalized institutions are expected to experience a neutral or positive stock market reaction to the new regulatory framework. Nevertheless, differences in the results might emerge if considering standard leverage (i.e. equity to assets ratio) rather than risk-weighted capital ratios (i.e. TIER1 ratio and CET1 ratio). Acharya and Steffen (2014) argue that the amount of bank capital shortfall found under the ECB's 2014 CA was around twenty times larger than reported. In their view, that underestimation is due to the adoption of inadequate measures of banks' capital ratios, based on regulatory risk-weights. ${ }^{19}$ Barucci et al. (2018) confirm the superiority of a standard leverage measure over risk-adjusted ratios in reflecting banks' risk.

Alongside capital holdings, bank liquidity represents a crucial and complementary element in promoting the resilience and soundness of the banking sector. A bank which is unable to roll over maturing debt can fail despite being solvent. When considering the bank CDS market, more liquid institutions are expected to reveal a smaller reaction than less liquid ones. Neutral or positive stock price reactions are expected for more liquid banks in response to the implementation of the BU because they are perceived safer compared to less liquid institutions.

The presence of a high volume of Non-Performing Loans (NPLs) on a bank's balance sheet adversely impacts its profitability because increased provisions are required, which in turn lower

\footnotetext{
18 Pairwise correlation coefficients between the variables are not reported, but we note that any pairs of variables revealing a correlation coefficient above 0.7 are excluded from use in the same model specification. Although the correlation coefficients for TIER1_RATIO and LEVERAGE_T do not pose any concerns in terms of potential multicollinearity, the variables are still considered separately as alternatives. Justification is provided in Section 4.1.

19 The ECB approach in assessing capital requirements is heavily dependent on the regulatory capital ratios established under the Basel accords (Acharya, Engle and Pierret, 2014).
} 
the net income. Impaired assets might also constrain significant amounts of capital due to the associated higher risk-weights, as well as hampering banks' capacity to provide new lending. Deterioration in asset quality also affects banks' funding costs, thus increasing investors' risk perception. NPLs for European banks were estimated to value about $€ 1$ trillion at June 2015, equivalent to $7.3 \%$ of the EU's GDP (EBA, 2015). The highest levels of NPLs were evidently in southern euro area countries. Since high volumes of NPLs place a huge burden on banks' balance sheets, and low-quality loan portfolios influence the probability of default, the proxy for the asset quality is expected to have a negative and sizeable influence on the CDS market response to the implementation of the BU. Stock prices of credit institutions characterized by high levels of NPLs are expected to react negatively to the implementation of the new European regulatory framework.

Larger credit institutions, with cross-country activities, pose a greater risk at the systemic level and are a target group for the new regulatory regime. These banks are expected to demonstrate an abnormal increase in their CDS premia, while revealing a negative stock market reaction to the regulatory implementation. Stock prices of banks characterized by sufficiently stable funding sources (thus having a reduced level of maturity mismatch) are expected to react less than those of institutions with more volatile funding structures. A higher reliance on shortterm liabilities is harmful for banks' stability. Similarly, banks which are more oriented to traditional intermediation, with an adequate level of asset diversification and with less risk appetite, are expected to demonstrate less pronounced abnormal increases in CDS premia (and a relatively benign stock market reaction) compared with riskier counterparties. Lastly, banks with the capability to generate and/or maintain greater profitability are expected to reveal smaller abnormal reactions in the CDS market. More profitable institutions might reveal positive ARs in the stock market compared to less profitable competitors.

\subsection{Regression model}

We regress the CARs arising from the univariate investigation on the selected bank-specific variables. The baseline empirical model, adopted for the analysis on both the CDS and stock markets, is represented by the following equation:

Equation 5

$$
\begin{aligned}
C A R_{i, t}=\alpha_{0}+ & \beta_{1}(T I E R 1)+\beta_{2}(N P L)+\beta_{3}(T A)+\beta_{4}\left(S T_{-} F\right)+\beta_{5}\left(L O A N_{-} T A\right)+\beta_{6}(I N T) \\
& +\beta_{7}\left(N_{-} I N T\right)+\beta_{8}\left(R W A_{-} T A\right)+\gamma(E V)+\varepsilon_{i, t}
\end{aligned}
$$

where $C A R_{i, t}$ of bank $i$ is calculated over a 3-day event window. TIER1 is the ratio of tier1 capital to risk-weighted assets (proxy for capitalization). NPL is the ratio of non-performing loans to gross loans (proxy for asset quality). TA is the natural logarithm of total assets (proxy for bank size). ST_F is the ratio of deposits and short-term funding to total assets (proxy for funding structure). LOAN_TA is the ratio of net loans to total assets (proxy for business model). INT is the 
ratio of interest income to average earning assets (proxy for profitability). N_INT is the ratio of non-interest income to gross revenues (proxy for diversification). RWA_TA is the ratio of riskweighted assets to total assets (proxy for ex-ante risk taking). EV is a vector of dummies for the selected 17 announcement dates. Regressions with bank fixed effects are run for the whole sample of banks and sub-groups. Robust standard errors are clustered at bank-year level (Petersen, 2009; Thompson, 2011).

\section{Empirical results}

\subsection{Univariate analysis}

\subsubsection{CDS market: Reaction to key BU announcement dates}

Table 6 reports the CAARs for the entire sample and banks' sub-groups. In order to provide an overview of the market reactions associated with the announcements on a common theme, Table 7 displays the aggregate coefficients. The figures in both Panels A and B of Table 7 are the outcomes of an aggregation across events of the same nature (i.e. "supervision", "Comprehensive Assessment", "resolution").

Considering only the statistically significant coefficients (Panel B of Table 7), all the subgroups demonstrate positive CAARs for the seven announcements related to the new supervisory framework. The relatively large value (+7.17bps) reported for the G-SIBs might be associated with the prospect of more demanding and intensive oversight. Negative aggregate CAARs (especially pronounced for GIIPS and G-SIBs) associated with the eight sub-events relating to the ECB's CA are likely to reflect the beneficial effect of the CA in enhancing transparency and soundness of the European banking sector. Referring to Table 6, while an increase in bank CDS spreads is reported for the CA announcement on 23 October 2013, further clarification and disclosure of more information on the procedure proved to be highly informative to the market and contributed to lowering the risk associated with banking activity. The fourth, fifth and sixth ECB announcements on the CA (i.e. 29 April 2014, 17 July 2014 and 8 August 2014) are found to convey valuable information to the market, with investors perceiving lower bank default risk. ${ }^{20} \mathrm{An}$ abnormal drop in CDS spreads is associated with the disclosure of the CA results on 27 October 2014, which is particularly pronounced for banks headquartered in GIIPS countries ( $-4.89 \mathrm{pbs})$. These findings provide support to the view that the CA provided new information to the CDS market, while promoting greater financial stability.

Regarding the resolution announcements (events 5 and 9), the aggregate significant CAARs are positive for all groups of banks (Table 7, Panel B). The negative and significant CAARs associated with the initial formal announcement on the SRM are offset by the large positive coefficients for the second announcement on 20 March 2014. This evidence might be attributable

20 The announcements relate to the (i) ECB position on the way to address bank capital shortfalls resulting from the CA, (ii) the release of the template to disclose the results and (iii) the publication of the CA and stress test manual (refer to Table 3). 
to an unclear and preliminary framework for the new bank resolution procedures. Indeed, while bank CDS spreads declined in reaction to the first announcement, sovereign CDS spreads strongly increased (particularly for GIIPS countries). ${ }^{21}$ This could imply that, in the short-term, the market perception of possible government bail-outs for distressed banks was still strong and dependent on the specific countries' fiscal conditions. Narrowing the discussion on the coefficients associated with the announcement number 9, which is considered as a milestone of the new bank resolution regime, they are positive and highly significant for each bank sub-groups (Table 6). An increase in the perceived level of banks' riskiness, as a consequence of the bail-in philosophy implied in the new resolution rules, could have been reflected in higher associated CDS spreads. The latter evidence, moreover, seems to be particularly significant for the group of G-SIBs (+7.43bps), which have been perceived to benefit from explicit and implicit government guarantees over a lengthy earlier time period (Moenninghoff et al., 2015; Leonello, 2018).22

\subsubsection{Stock and stock futures markets: Reactions to key BU announcement dates}

Table 8 reports in detail the CAARs for the entire sample and the banks' sub-groups. Following the same approach as for the CDS market, Table 9 displays the aggregate CAARs, classified according to the nature of the ECB official announcements.

The univariate analysis on the stock market produces results which mirror (and therefore support) the findings for the CDS market. The whole sample reveals negative CAARs for the seven announcements related to the single supervisory regime $(-1.49 \%)$, positive CAARs across the eight announcements related to the CA (+6.96\%) and negative aggregate coefficients in association with the two announcements on the new bank resolution regime $(-2.04 \%)$. If one considers only the statistically significant coefficients (Panel B of Table 9), the corresponding figures become -3.01\% (supervision events n. 2, 10 and 16), $+7.80 \%$ (CA events n. 4, 8 and 14) and $-1.10 \%$ (resolution event n. 5).

With respect to the implementation of the single supervisory architecture, investors in the stock market, rather than rewarding the convergence towards a common supervisory culture, seem more concerned by the prospect of a more intrusive and costly regime. The initial positive sentiment recorded upon Mario Draghi welcoming the agreement on the SSM, in September 2013, was followed by a significant negative reaction to the announcement on the regulation on the supervisory fees (i.e. event n.16, 30 October 2014). ${ }^{23}$ Angeloni (2018) and Bruno and Carletti (2019) highlight the necessity to reduce the complexity and costs of the current multi-structured supervisory framework.

\footnotetext{
${ }^{21}$ Although not presented in this version of the paper, we also investigated the sovereign CDS market response to the key BU announcements.

${ }^{22}$ Similar findings arise from the analysis conducted on a 1-day event window. On 20 March 2014, the estimated coefficient for the group of G-SIBs is $+9.60 \mathrm{bps}$, significant at the $1 \%$ level according to both the parametric and nonparametric significance tests (refer to Section 6 and Table 14).

${ }^{23}$ At the bank level, fees are calculated on the basis of the importance and the risk profile of the supervised entity. Since markets' response to regulatory events depends on both the costs and benefits associated with the new proposed rules, the interpretation of the reactions broadly relies on how markets evaluate these costs and benefits (Gao et al., 2018).
} 
The stock market reaction is shown to promote the effectiveness of the CA in shedding more light on the euro area banking sector. Positive reactions are noteworthy for the events n. 8 and 14, and more pronounced for the sub-group of banks located in GIIPS countries $(+13.27 \%$ and $+2.67 \%$, respectively). The enhanced transparency is reflected in increasing bank stock prices. This positive outcome has been potentially enlarged by the fact that several banks improved their capital position ahead of the CA, with consequent beneficial effects for the stability of the entire system. Differing from Carboni et al. (2017), but consistent with Sahin and de Haan (2016), bank stock prices of all sub-groups do not significantly react on the day associated with the disclosure of the CA results (event n.15). ${ }^{24}$ Finally, negative market responses are associated with the two announcements on the bank resolution regime. Nevertheless, only the coefficients associated with the first announcement (i.e. event n. 5) present some marginal statistical significance, with the euro area banks showing the strongest reaction (-1.29\%).

As anticipated, the sub-group including banks located in European but non-euro area countries demonstrates a different outcome to the other bank groups. It reveals positive significant CAARs $(+1.90 \%)$ for the seven announcements related to the supervision regime and nearly close to zero CAARs related to the eight announcements on the CA $(+0.17 \%)$. The coefficients associated with the two announcements on the resolution framework are both insignificant. The positive response to the implementation of the common supervision seems to suggest a competitive advantage, at least in the short-term, for the institutions outside the euro area. Lastly, contrary to a prior expectation, it is noteworthy that G-SIBs demonstrate small and insignificant CAARs across all the 17 selected announcements.

The evidence found for the stock futures market is mixed. The investors' responses to the various announcements on the single supervisory framework are positive for all the considered bank groups (Table 11, Panel B). The most pronounced reaction is recorded for banks in GIIPS countries $(+2.49 \%)$. This evidence contrasts with the findings for the stock market, suggesting a different perception among participants in the derivatives market regarding the beneficial effects of the convergence towards common supervisory rules. Positive and significant coefficients are shown in correspondence to the third and seventh announcement on the SSM (Table 10). When considering the announcements on the CA, the direction of the market reaction is overall aligned with that found for the stock market (Table 11, Panel A). Nevertheless, when looking only at the significant coefficients (Table 11, Panel B), the responsiveness of the stock futures market is very limited. The same consideration holds when focusing on the announcements on the new bank resolution rules. Although, at least in principle closely related to the stock market, movements in the derivatives market do not highlight any particular sensitivity to the implementation of the new mechanisms within the BU architecture. This can potentially reflect the better informed

${ }^{24}$ This finding is also consistent when using a different proxy for the stock market (i.e. MSCI Europe Index) and when focusing on a 1-day event window (refer to Section 6 on the robustness checks). 
constituency in the futures market, in the sense that there is less "surprise" content in the announcements. Such evidence is an important additional contribution of this paper.

\subsection{Multivariate analysis}

\subsubsection{CDS market regression results}

The estimated results for the regression analysis on both the entire sample of banks as well as each sub-group are reported in Table 12. The findings suggest that, as anticipated, the level of capitalization (captured by the TIER1_RATIO variable) has an inverse link with the dependent variable (CARs). Nevertheless, the coefficients are not significantly different from zero. For the GSIBs, the positive and statistically significant coefficient could arise because market participants associate a higher riskiness to increasing levels of capital, due to these banks' systemic relevance. Moreover, "forcing banks to raise expensive capital because future profitability is unclear increases the probability of future non-viability" (Financial Times, 2016). ${ }^{25}$ When considering the top-quality capital, the CET1 ratio, the associated coefficient for the G-SIBs, although still positive, is not significant, while for the sub-group of banks situated in GIIPS countries the ratio has a negative and significant coefficient (-1.711 significant at the $5 \%$ level). ${ }^{26}$

Contrary to prior expectations, the coefficient for the proxy of the loan portfolio quality, i.e. NPL, is negative (although small) and insignificant for the largest groups of banks (full sample, banks located in euro area countries and credit institutions operating in peripheral euro area economies). However, it is positive and significant for the remaining two sub-groups. A coefficient of 1.100 , significant at the $5 \%$ level, is obtained for banks located in non-euro area countries, while for the G-SIBs a one percentage point increase in the NPL ratio is associated with an (abnormal) increase in the CDS spreads of around 3bps. For these two sub-groups, underlying weak credit quality seems to be a relevant factor in explaining abnormal movements (increases) in CDS spreads. The latter evidence holds also in the model specification including the CET1 as an alternative proxy for bank capitalization.

Abnormal changes in CDS premia are not sensitive to the bank's size (captured by the level of total assets). This evidence could depend on the perceived lack of proportionality in the new European banking framework. The proxy for the funding structure, given by the amount of deposits and short-term funding over the total assets, yields positive coefficients for four out of five sub-groups of banks, although statistically different from zero only for the full sample $(0.272$, significant at the $5 \%$ level). For the G-SIBs, the coefficient has a negative sign $(-0.355)$ and is significant at the $5 \%$ level. In this case, a greater reliance on short-term funding and, thus, a higher level of liquidity seems to contribute in lowering the probability of potential distress, which is in turn reflected in lower CDS spreads.

25 See www.ft.com/content/058b4ee0-d0c9-11e5-831d-09f7778e7377.

26 When considering the standard leverage ratio none of the estimated coefficients is significant. These results are not tabulated in the current version of the paper. 
The net loans to total asset ratio (indicating the business model orientation), has a negative and significant coefficient of 0.362 in the regression for the full sample. The coefficient is negative, although insignificant, for the sub-sample of banks located in euro area countries. In the remaining cases, the sign is positive but insignificant. In contrast to this mixed evidence, when including the CET1 as the proxy for bank capitalization, a negative and significant relationship between euro area banks' business model orientation and CDS spreads changes is revealed.

The estimated coefficients for bank profitability (defined as the ratio of interest income over average earning assets) have the predicted negative relationship with CARs for the subgroups of (i) banks located in GIIPS countries (-3.687); (ii) G-SIBs (-3.010); and (iii) banks located outside euro area countries (-3.914). Nevertheless, it is only for the latter category that the coefficient is statistically significant at the $5 \%$ level. The profitability indicator for GIIPS banks turns statistically significant at the $1 \%$ level in the model specification including the CET1. Consistent with initial expectations, when significant, banks' perceived probability of distress increases with lower levels of profitability.

The degree of diversification in banking activities, captured by the ratio of non-interest income to gross revenues, has a positive association with CARs in the CDS market for the main bank sub-groups (ALL, EU_EZ and GIIPS). The estimated coefficient is marginally significant only for the group of banks located in peripheral economies ( 0.310 and significant at the $10 \%$ level). This positive relation suggests that a higher reliance on non-interest income might be perceived as a factor which contributes in increasing a bank's riskiness, reflected in higher CDS spreads. For the group of banks located outside the euro area (EU_NONEZ) and G-SIBs, the relation is instead negative and highly significant (the coefficients are -0.097 and -0.475 , respectively). In line with the prior literature, it is not clear whether a more diversified income structure and, specifically, the reliance on the non-interest component, has a beneficial impact in lowering banking default risk (see, among others, Altunbas et al., 2017).

Finally, the ratio of risk-weighted assets over total assets, which represents the proxy for the ex-ante risk taking, demonstrates a mixed and marginal effect on the level of CDS spreads. It has negative coefficients for the whole sample and the sub-group of banks located outside the euro area, although marginally significant only in the latter case ( -0.070 significant at the $10 \%$ level). Otherwise it yields positive coefficients, significant only for the sub-sample located in peripheral countries (0.239 and significant at the $10 \%$ level).

\subsubsection{Stock market regression results}

For the full sample of banks, the TIER1_RATIO yields a positive coefficient of 0.200 that is statistically significant at the $5 \%$ level (Table 13). In the case of institutions located in euro area countries (EU_EZ) the coefficient remains positive and highly significant (at the $1 \%$ level). A higher level of capitalization is associated with positive abnormal performance in the stock market. This seems especially true in the case of euro area banks, for which a one percentage point increase in 
the TIER1 ratio is associated with an (abnormal) increase in the stock prices of around $0.38 \%$. Similar results, showing stronger statistical significance, are also obtained when considering a standard non-risk based leverage measure (i.e. the assets to equity ratio). The stock market reaction of banks located in euro area countries is positively affected by their level of capitalization (on average significant at the $5 \%$ level). In contrast, the level of capitalization has a negative coefficient for both banks located outside euro area countries and G-SIBs, which is statistically significant at the 5\% level. The outcomes obtained when using the CET1 ratio demonstrate a sign consistent with the other two cases. ${ }^{27}$

The coefficient on the proxy variable for credit quality (i.e. NPL) is generally negative and insignificant, except for the G-SIBs sub-group for which it assumes a positive and highly significant value (0.667). This might be interpreted as a sign of positive sentiment by the market participants towards the credibility of the new regulatory framework in strengthening the resilience of these banks by pressing them to resolve the NPL situation. It is worthwhile to mention the substantial efforts of the SSM in tackling the NPL problem within the European banking sector.

The level of total assets (bank size) has a mixed impact on the stock market responses. The estimated coefficient is negative in the regressions for (i) the full sample; (ii) the sub-group of banks located in GIIPS countries; and (iii) banks in non-euro area countries. Nevertheless, the coefficient (-5.595) is only significant in the latter case (at the $5 \%$ level). This might imply that shareholders of large institutions outside the scope of the BU are sensitive to potential disadvantages of their absence from the new centralised banking framework. For the remaining sub-groups, the coefficient is positive and, in the case of G-SIBs, pronounced although not statistically significant.

The proxy for the funding structure, defined as the ratio of deposits and short term funding to total assets, reveals relatively weak and not significant coefficients in all the regressions. The net loans to total assets ratio, indicating the business model orientation, is positively associated with banks' stock price reaction. The largest coefficient (0.595), which is statistically significant at the $1 \%$ level, is obtained for the G-SIBs. Stock prices of banks with business models more orientated to traditional activities, since potentially less risky, positively react to the implementation of the new regulatory regime.

The profitability indicator is generally positively related to the stock market reactions. This confirms the prior hypothesis that more profitable banks were expected to reveal positive abnormal performance compared to less profitable ones. Unexpectedly, for G-SIBs and institutions located outside the euro-area, the coefficient is negative and significant. For G-SIBs, the magnitude of the coefficient is noteworthy $(-3.469$, significant at the $5 \%$ level) suggesting a non-favourable market sentiment towards a highly performing, yet potentially risky, banking activity.

\footnotetext{
${ }^{27}$ In the interests of brevity, the estimated results for the regressions which include the ordinary leverage ratio or the CET1, as proxies for the level of capitalization, are not tabulated in this version of the paper.
} 
The degree of diversification in banking activities demonstrates a mixed association with stock price reactions. It yields a positive and significant coefficient for both the whole sample and the sub-group of banks located outside the euro area (0.044 and 0.102, respectively). Lastly, the ratio of risk-weighted assets to total assets (the proxy for ex-ante risk taking) appears significant only in the case of banks located outside euro countries. Furthermore, the relatively weak coefficient of 0.087 has a negative sign.

\section{Robustness checks}

This section reports some robustness checks on the results from the univariate analysis. More specifically, for the CDS and stock market the investigation was repeated by focusing on a 1day event window. Findings for the analysis on the CDS market are the more interesting ones (see Table 14). Overall, a greater extent of statistical significance is revealed. Consistent with the main analysis, the coefficients associated with the announcement date considered as a cornerstone of the new banking resolution regime (i.e. 20 March 2014) are positive and highly significant for each of the bank sub-groups. The aggregate impact of the eight announcements on the CA is negative, in line with the results from our main investigation. Nevertheless, an abnormal upsurge in the CDS market is reported on the CA announcement date (i.e. 23 October 2013). When focusing on the exact date of the events, the disclosure of the CA process (i.e. 17 July 2014) is associated with an increase in the level of banks' CDS spreads. A negative sentiment, reflected in increasing CDS spreads, is also associated with the announcement related to the official launch of the SSM in November 2014. Uncertainty about the future oversight regime, combined with higher compliance costs, could motivate market participants' reaction, at least in the short-run. In Table 15, for the stock market, the coefficients are of the same direction as in Table 8 with the 3-day window, but generally less strongly significant. ${ }^{28}$

\section{Conclusions}

This paper provides detailed insights on the financial market sentiment surrounding the initial steps towards a BU in Europe. By adopting an event study methodology, we investigate the CDS, stock and stock futures markets' reactions to each announcement date preceding the start of the SSM. Furthermore, we also capture the heterogeneity in the reactions across different banks' sub-groups and investigate how financial market responses are associated with bank-specific variables.

The first stage of the empirical analysis focuses on the impact of the BU announcements on three different financial markets. The findings demonstrate that the announcements related to the implementation of the new supervisory mechanism led to a general increase in banks' CDS spreads, especially pronounced for the group of G-SIBs. Corresponding to the announcements on

\footnotetext{
28 The analysis was also conducted using a non-industry specific index, i.e. the MSCI Europe Index. Although a larger magnitude of the significant coefficients is found, the inferences are not altered. In the interests of brevity, these results are not tabulated in the paper.
} 
the CA, negative abnormal changes in the CDS spreads were revealed. Market participants positively assessed the contribution of the exercise in enhancing transparency and reducing the risk associated with banking activity. Finally, positive coefficients were reported for announcements on the new bank resolution rules, reflecting a rise in CDS prices. This indicates a potential increase in the perceived level of banks' debt riskiness linked to the bail-in philosophy underlying the new European procedures for the resolution of ailing banks. Interestingly, CDS of GSIBs were shown to significantly react to the implementation of the BU project. Their impending subjection to enhanced supervision and higher capital requirements, combined with a potentially reduced degree of public support, might motivate this finding.

The abnormal event-induced movements in the stock market were consistent with the evidence reported for the CDS market. Banks' stock prices reacted in a consistent manner with the CDS market. The implementation of the new supervisory component had a negative effect on banks' stock prices. This evidence could be attributed to the (higher) compliance costs associated with more complex and demanding oversight of banks. The market responses to the key announcements on the CA were strongly positive for all bank groups. This result underlines the beneficial effect of an increased level of transparency combined with the fact that several banks improved their capital position in advance of the CA procedure. Announcements on the new European resolution rules had a negative impact on all banks' stocks. However, stock prices of banks located in European but non-euro area countries showed the most limited reaction, while stock prices of G-SIBs did not show any significant response. The univariate analysis on the stock futures market did not highlight any specific pattern of sensitivity in response to the changes in the European regulatory landscape. The latter evidence is consistent with the likely presence of better informed participants active in the derivatives market.

The multivariate analysis demonstrated that the degree of capitalization is commonly in a negative association with abnormal movements in the CDS market. However, for the sub-group of G-SIBs a direct relationship is detected. This evidence might indicate that market participants perceived a higher riskiness indicated by increasing levels of capital. Furthermore, the imposition through regulatory actions of raising costly capital, because of future uncertain profitability, can increase the probability of non-viability in the long-term. Regardless of their levels of capital, institutions which are incapable of generating profits are not safe. For banks located in non-euro area countries and the G-SIBs, a weak underlying credit quality is an influential factor in explaining abnormal increases in CDS spreads. Overall, bank-specific features for the sub-sample of G-SIBs were demonstrated to particularly affect reactions of the CDS market. The corresponding analysis on the stock market revealed positive associations of the CARs with capital levels and business model orientation. A higher level of capitalization, especially when captured by a non-risk based leverage measure, was associated with positive abnormal performance in the stock market. The same consideration held for the stock prices of banks with a business model more focused on traditional activities. 
The need for strengthening bank supervisory and regulatory integration in Europe was inevitable once the inherent contradiction existing in its financial architecture was recognised. More unified financial markets across countries existed alongside fragmentation of banking oversight and banking safety nets along domestic lines. Fostering financial stability and banking integration in Europe was thus a central aim of BU, while addressing the incompleteness of the Monetary Union. Higher supervisory standards, based on independence and transparency, and complemented by a common resolution framework were perceived by the markets as beneficial in improving the resilience of the euro area banking sector. On the other hand, the higher compliance and regulatory costs associated with the new mechanisms were negatively received by investors. In this view, the potential for distortive competitive incentives among larger, and directly supervised institutions, and smaller banks (i.e. less significant banks) could hinder the creation of a real level playing field in the euro area. Retaining an appropriate balance between the objectives of central and national mechanisms is therefore crucial, from the perspective of achieving a greater level of harmonisation. Furthermore, an incomplete BU, lacking its third pillar (i.e. a euro area deposit insurance), also represents an additional source of uncertainty and risk affecting economic and financial stability (Angeloni, 2018). Therefore, European policymakers should develop a coherent strategy with the aim of limiting these risks, which involves clear objectives and a rapid implementation timeline. 


\section{References}

Acharya, V.V., Drechsler, I. \& Schnabl, P. 2014. A pyrrhic victory? - Bank bailouts and sovereign credit risk. Journal of Finance 69, pp. 2689-2739.

Acharya, V.V. \& Steffen, S. 2014. Falling short of expectations? Stress testing the European banking system. CEPS Policy Brief No. 315.

Acharya, V.V. \& Steffen, S. 2015. The "greatest" carry trade ever? Understanding eurozone bank risks. Journal of Financial Economics 115, pp. 215-236.

Acharya, V.V., Engle, R. \& Pierret, D. 2014. Testing macroprudential stress tests: The risk of regulatory risk weights. Journal of Monetary Economics 65, pp. 36-53.

Aggarwal, N. \& Thomas, S. 2019. When stock futures dominate price discovery. Journal of Futures Markets 39, pp. 263-278.

Altunbas, Y., Manganelli, S. \& Marques-Ibanez, D. 2017. Realized bank risk during the great recession. Journal of Financial Intermediation 32, pp. 29-44.

Angeloni, I. 2018. ECB supervision at 5: Challenges, opportunities and wishes. Speech at the Official Monetary and Financial Institutions Forum, London, December 2018.

Angeloni, I. 2019. Supervisory independence. Speech at the ECB colloquium "Challenges for Supervisors and Central Bankers", Frankfurt am Main, March 2019.

Back, K. 1993. Asymmetric information and options. Review of Financial Studies 6, pp. 435-472.

Barucci, E., Baviera, R. \& Milani, C. 2018. The Comprehensive Assessment: What lessons can be learned? European Journal of Finance 24, pp. 1253-1271.

Bayazitova, D. \& Shivdasani, A. 2012. Assessing TARP. Review of Financial Studies 25, pp. 377-407.

Berger, B., Hüttl, P. \& Merler, S. 2016. Total assets versus risk weighted assets: Does it matter for MREL? Bruegel Policy Contribution, July 2016.

Binder, J.J., 1998. The event study methodology since 1969. Review of Quantitative Finance and Accounting 11, pp. 111-137.

Black, F. 1975. Fact and fantasy in the use of options. Financial Analysts Journal 31, pp. 36-41, 6172.

Boehmer, E., Musumeci, J. \& Poulsen, A.B. 1991. Event-study methodology under conditions of event-induced variance. Journal of Financial Economics 2, pp. 253-272.

Bruno, B. \& Carletti, E. 2019. European banking supervision: Stock-taking and next steps. European Parliament, In-Depth Analysis, March 2019.

Bruno, B., Onali, E. \& \& Schaeck, K. 2018. Market reaction to bank liquidity regulation. Journal of Financial and Quantitative Analysis 53, pp. 899-935.

Carboni, M., Fiordelisi, F., Ricci, O., \& Stentella Lopes, F.S. 2017. Surprised or not surprised? The investors' reaction to the comprehensive assessment preceding the launch of the banking union. Journal of Banking and Finance 74, pp. 122-132.

Chiaramonte, L. \& Casu, B. 2013. The determinants of bank CDS spreads: Evidence from the financial crisis. European Journal of Finance 19, pp. 861-887.

Conlon, T., Cotter, J. 2014. Anatomy of a bail-in. Journal of Financial Stability 15, pp. 257-263.

Constâncio, V. 2014. Banking Union: Meaning and implications for the future of banking. Speech at Banking Union Conference organized by the Master in Banking and Financial Regulation, Navarra University, April 2014.

Cowan, A.R. 1992. Nonparametric event study tests. Review of Quantitative Finance and Accounting 4, pp. 343-358. 
Dell'Ariccia, G., Martinez Peria, M.S., Igan, D., Awadzi, E.A., Dobler, M. \& Sandri, D. 2018. Trade-offs in bank resolution. IMF Staff Discussion Note, February 2018.

Ejsing, J. \& Lemke, W. 2011. The Janus-headed salvation: Sovereign and bank credit risk premia during 2008-2009. Economics Letters 110, pp. 28-31.

Enria, A. 2019. Supervising banks - Principles and priorities. Speech at the SSM and Boardroom Dialogue, Frankfurt am Main, March 2019.

Gao, Y., Liao, S. \& Wang, X. 2018. Capital markets' assessment of the economic impact of the DoddFrank Act on systemically important financial firms. Journal of Banking and Finance 86, pp. 204-223.

Goyal, R., Brooks, P.K., Pradhan, M., Tressel, T., Dell'Ariccia, G., Leckow, R., \& Pazarbasioglu, C. 2013. A Banking Union for the euro area. IMF Staff Discussion Note, February 2013.

Herring, R.J. 2013. The danger of building a Banking Union on a one-legged stool. In: F. Allen, E. Carletti \& J. Gray (eds). Political, Fiscal and Banking Union in the Eurozone? Wharton Financial Institutions Center edn. University of Pennsylvania: Philadelphia, USA. pp. 9-28.

Horváth, B.L. \& Huizinga, H. 2015. Does the European Financial Stability Facility bail out sovereigns or banks? An event study. Journal of Money, Credit and Banking 1, pp. 177-206.

Hull, J., Predescu, M. \& White, A. 2004. The relationship between credit default swaps spreads, bond yields, and credit rating announcements. Journal of Banking and Finance 28, pp. 27892811.

IMF, 2014. Moving from liquidity to growth driven markets. Global Financial Stability Report, April 2014.

Jain, S., Agarwalla, S.K., Varma, J.R. \& Pandey, A. 2019. Informed trading around earnings announcements: Spot, futures or options? Journal of Futures Markets 39, pp. 579-589.

Karafiath, I., 1994. On the efficiency of least squares regression with security abnormal returns as the dependent variable. Journal of Financial and Quantitative Analysis 29, pp. 279-300.

Kolari, J.W. \& Pynnönen, S. 2010. Event study testing with cross-sectional correlation of abnormal returns. Review of Financial Studies 11, pp. 3996-4025.

Leonello, A. 2018. Government guarantees and the two-way feedback between banking and sovereign debt crises. Journal of Financial Economics 130, pp. 592-619.

Lin, C.B., Chou, R.K. \& Wang, G.H.K. 2018. Investor sentiment and price discovery: Evidence from the pricing dynamics between the futures and spot markets. Journal of Banking and Finance 90, pp. 17-31.

MacKinlay, A.C., 1997. Event studies in economics and finance. Journal of Economic Literature 35, pp. 13-39.

McWilliams, A. \& Siegel, D., 1997. Event studies in management research: Theoretical and empirical issues. Academy of Management Journal 40, pp. 626-657.

Moenninghoff, S.C., Ongena, S. \& Wieandt, A. 2015. The perennial challenge to counter Too-Big-toFail in banking: Empirical evidence from the new international regulation dealing with Global Systemically Important Banks. Journal of Banking and Finance 61, pp. 221-236.

Morgan, D.P., Peristiani, S., Savino, V. 2014. The information value of the stress test. Journal of Money, Credit and Banking 46, pp. 1479-1500.

Needham, D. 1983. Economics and politics of regulation: A behavioral approach. Boston: Little, Brown. 
Norden, L., Roosenboomand, P. \& Wang, T. 2013. The impact of government intervention in banks on corporate borrowers' stock returns. Journal of Financial and Quantitative Analysis 5, pp. 1635-1662.

Norden, L. \& Weber, M. 2004. Informational efficiency of credit default swap and stock markets: The impact of credit rating announcements. Journal of Banking and Finance 11, pp. 28132843.

Petersen, M.A. 2009. Estimating standard errors in finance panel data sets: Comparing approaches. Review of Financial Studies 1, pp. 435-480.

Petrella, G. \& Resti, A. 2013. Supervisors as information producers: Do stress tests reduce bank opaqueness? Journal of Banking and Finance 37, pp. 5406-5420.

Sahin, C. \& de Haan, J. 2016. Market reactions to the ECB's Comprehensive Assessment. Economics Letters 140, pp. 1-5.

Schäfer, A., Schnabel, I. \& di Mauro, B.W. 2016. Financial sector reform after the Subprime crisis: Has anything happened? Review of Finance 20, pp. 77-125.

Schoenmaker, D. \& Siegmann, A. 2013. Efficiency gains of a European Banking Union. Tinbergen Institute Discussion Papers, 13-026/IV/DSF51.

Schwert, G.W. 1981. Using financial data to measure effects of regulation. Journal of Law \& Economics 1, pp. 121-158.

Sclip, A., Girardone, C. \& Miani, S. 2019. Large EU banks' capital and liquidity: Relationship and impact on credit default swap spreads. British Accounting Review (forthcoming).

Steffen, S. 2014. Robustness, Validity and significance of the ECB's Asset Quality Review and stress test exercise. ESMT European School of Management and Technology.

Thompson, S.B. 2011. Simple formulas for standard errors that cluster by both firm and time. Journal of Financial Economics 99, pp. 1-10.

Véron, N. 2015. Europe's radical banking union. Bruegel Essay and Lecture series.

Veronesi, P. \& Zingales, L. 2010. Paulson's gift. Journal of Financial Economics 3, pp. 339-368. 
Table 1: Expected impact on CDS, stock and stock futures markets of the implementation of the BU

\begin{tabular}{|c|c|c|c|}
\hline Event & $\begin{array}{c}\text { Expected impact on bank } \\
\text { CDS market }\end{array}$ & $\begin{array}{c}\text { Expected impact on bank stock \& } \\
\text { stock futures markets }\end{array}$ \\
\hline $\begin{array}{c}\text { Implementation } \\
\text { of the BU }\end{array}$ & $\begin{array}{c}\text { Application of } \\
\text { new bail-in rules }\end{array}$ \\
\cline { 2 - 4 } & Adverse impact on profitability \\
Reduction of \\
banking system \\
riskiness
\end{tabular}

Description: The table presents the main hypotheses regarding the impact of the implementation of the BU on the three selected financial markets. 
Table 2: Data sample

\begin{tabular}{|c|c|c|c|c|c|c|c|c|c|}
\hline & & & & $\begin{array}{r}\text { Com } \\
\text { As: }\end{array}$ & $\begin{array}{l}\text { ensive } \\
\text { nent }\end{array}$ & & & & \\
\hline$\#$ & Bank Name & Country & $\begin{array}{c}\text { Tot. Asset } \\
\text { (m €) }\end{array}$ & AQR & $\begin{array}{c}\text { Stress } \\
\text { Test }\end{array}$ & SSM & CDS & Futures & G-SIBs \\
\hline 1 & ERSTE GROUP BANK & AT & 199,157 & $\checkmark$ & $\checkmark$ & $\checkmark$ & $\checkmark$ & & \\
\hline 2 & DEXIA & $\mathrm{BE}$ & 222,894 & $\checkmark$ & $\checkmark$ & $\checkmark$ & & $\checkmark$ & \\
\hline 3 & KBC GROUP & $\mathrm{BE}$ & 239,825 & $\checkmark$ & $\checkmark$ & $\checkmark$ & $\checkmark$ & & \\
\hline 4 & COMMERZBANK & $\mathrm{DE}$ & 546,565 & $\checkmark$ & $\checkmark$ & $\checkmark$ & $\checkmark$ & & \\
\hline 5 & DEUTSCHE BANK & $\mathrm{DE}$ & $1,604,329$ & $\checkmark$ & $\checkmark$ & $\checkmark$ & $\checkmark$ & $\checkmark$ & $\checkmark$ \\
\hline 6 & DANSKE BANK & DK & 432,421 & & $\checkmark$ & & $\checkmark$ & & \\
\hline 7 & JYSKE BANK & DK & 35,119 & & $\checkmark$ & & & & \\
\hline 8 & SYDBANK & DK & 19,812 & & $\checkmark$ & & & & \\
\hline 9 & BANCO BILBAO VIZCAYA ARGENTARIA & ES & 570,993 & $\checkmark$ & $\checkmark$ & $\checkmark$ & $\checkmark$ & & \\
\hline 10 & BANCO DE SABADELL & ES & 157,225 & $\checkmark$ & $\checkmark$ & $\checkmark$ & $\checkmark$ & $\checkmark$ & \\
\hline 11 & BANCO POPULAR ESPANOL & ES & 144,709 & $\checkmark$ & $\checkmark$ & $\checkmark$ & $\checkmark$ & $\checkmark$ & \\
\hline 12 & BANCO SANTANDER & ES & $1,094,570$ & $\checkmark$ & $\checkmark$ & $\checkmark$ & $\checkmark$ & $\checkmark$ & $\checkmark$ \\
\hline 13 & BANKINTER & ES & 55,003 & $\checkmark$ & $\checkmark$ & $\checkmark$ & $\checkmark$ & $\checkmark$ & \\
\hline 14 & BNP PARIBAS & FR & $1,792,578$ & $\checkmark$ & $\checkmark$ & $\checkmark$ & $\checkmark$ & & $\checkmark$ \\
\hline 15 & CREDIT AGRICOLE & FR & $1,534,097$ & $\checkmark$ & $\checkmark$ & $\checkmark$ & $\checkmark$ & & $\checkmark$ \\
\hline 16 & SOCIETE GENERALE & FR & $1,229,166$ & $\checkmark$ & $\checkmark$ & $\checkmark$ & $\checkmark$ & & $\checkmark$ \\
\hline 17 & ALPHA BANK & GR & 70,908 & $\checkmark$ & $\checkmark$ & $\checkmark$ & $\checkmark$ & $\checkmark$ & \\
\hline 18 & EUROBANK ERGASIAS & GR & 74,523 & $\checkmark$ & $\checkmark$ & $\checkmark$ & & & \\
\hline 19 & NATIONAL BANK OF GREECE & GR & 108,521 & $\checkmark$ & $\checkmark$ & $\checkmark$ & $\checkmark$ & & \\
\hline 20 & OTP BANK & HU & 34,943 & & $\checkmark$ & & & $\checkmark$ & \\
\hline 21 & ALLIED IRISH BANK & IE & 113,906 & $\checkmark$ & $\checkmark$ & $\checkmark$ & & $\checkmark$ & \\
\hline 22 & GOV. COMP. BANK OF IRELAND & IE & 130,423 & $\checkmark$ & $\checkmark$ & $\checkmark$ & $\checkmark$ & $\checkmark$ & \\
\hline 23 & BANCA CARIGE & IT & 40,371 & $\checkmark$ & $\checkmark$ & $\checkmark$ & & $\checkmark$ & \\
\hline 24 & BANCA MONTE DEI PASCHI & IT & 194,936 & $\checkmark$ & $\checkmark$ & $\checkmark$ & $\checkmark$ & $\checkmark$ & \\
\hline 25 & BANCA PICCOLO CREDITO VALTELLINESE & IT & 26,704 & $\checkmark$ & $\checkmark$ & & & & \\
\hline 26 & BANCA POPOLARE DELL'EMILIA ROMAGNA & IT & 60,720 & $\checkmark$ & $\checkmark$ & $\checkmark$ & & & \\
\hline 27 & BANCA POPOLARE DI MILANO & IT & 48,507 & $\checkmark$ & $\checkmark$ & $\checkmark$ & $\checkmark$ & $\checkmark$ & \\
\hline 28 & BANCA POPOLARE DI SONDRIO & IT & 32,461 & $\checkmark$ & $\checkmark$ & $\checkmark$ & & & \\
\hline 29 & BANCO POPOLARE & IT & 123,190 & $\checkmark$ & $\checkmark$ & $\checkmark$ & $\checkmark$ & $\checkmark$ & \\
\hline 30 & CREDITO EMILIANO & IT & 31,346 & $\checkmark$ & $\checkmark$ & $\checkmark$ & & $\checkmark$ & \\
\hline 31 & INTESA SANPAOLO & IT & 615,304 & $\checkmark$ & $\checkmark$ & $\checkmark$ & $\checkmark$ & $\checkmark$ & \\
\hline 32 & MEDIOBANCA & IT & 72,192 & $\checkmark$ & $\checkmark$ & $\checkmark$ & $\checkmark$ & $\checkmark$ & \\
\hline 33 & UNICREDIT & IT & 827,217 & $\checkmark$ & $\checkmark$ & $\checkmark$ & $\checkmark$ & $\checkmark$ & $\checkmark$ \\
\hline 34 & UNIONE DI BANCHE ITALIANE & IT & 121,961 & $\checkmark$ & $\checkmark$ & $\checkmark$ & $\checkmark$ & $\checkmark$ & \\
\hline 35 & BANK OF VALLETTA & MT & 7,188 & $\checkmark$ & $\checkmark$ & $\checkmark$ & & & \\
\hline 36 & ING GROUP & $\mathrm{NL}$ & $1,079,244$ & $\checkmark$ & $\checkmark$ & $\checkmark$ & $\checkmark$ & $\checkmark$ & $\checkmark$ \\
\hline 37 & DNB Bank & NO & 285,681 & & $\checkmark$ & & $\checkmark$ & & \\
\hline
\end{tabular}




\begin{tabular}{|c|c|c|c|c|c|c|c|c|c|}
\hline 38 & BANK BPH & PL & 7,882 & & $\checkmark$ & & & & \\
\hline 39 & PKO BANK POLSKI & PL & 47,779 & & $\checkmark$ & & & $\checkmark$ & \\
\hline 40 & BANCO BPI & PT & 42,182 & $\checkmark$ & $\checkmark$ & $\checkmark$ & & & \\
\hline 41 & BANCO COMERCIAL PORTUGUES & PT & 79,825 & $\checkmark$ & $\checkmark$ & $\checkmark$ & $\checkmark$ & & \\
\hline 42 & NOVA KREDITNA BANKA MARIBOR & SI & 4,810 & $\checkmark$ & $\checkmark$ & $\checkmark$ & & & \\
\hline 43 & VSEOBECNA UVEROVA BANKA & SK & 11,514 & $\checkmark$ & $\checkmark$ & $\checkmark$ & & & \\
\hline 44 & NORDEA BANK & SE & 629,994 & & $\checkmark$ & & $\checkmark$ & $\checkmark$ & \\
\hline 45 & SVENSKA HANDELSBANKEN & SE & 281,293 & & $\checkmark$ & & $\checkmark$ & & \\
\hline 46 & SWEDBANK & SE & 205,686 & & $\checkmark$ & & $\checkmark$ & & \\
\hline 47 & BARCLAYS & UK & $1,571,466$ & & $\checkmark$ & & $\checkmark$ & & $\checkmark$ \\
\hline 48 & HSBC HOLDINGS & UK & $1,933,861$ & & $\checkmark$ & & $\checkmark$ & $\checkmark$ & $\checkmark$ \\
\hline 49 & LLOYDS BANKING GROUP & UK & $1,011,930$ & & $\checkmark$ & & $\checkmark$ & $\checkmark$ & \\
\hline 50 & ROYAL BANK OF SCOTLAND GROUP & UK & $1,231,250$ & & $\checkmark$ & & $\checkmark$ & $\checkmark$ & $\checkmark$ \\
\hline
\end{tabular}

Description: The table shows the list of banks included in the sample and their country of origin. It reports figures on banks' total assets as at 31/12/2013 (in line with the data used in the CA). It also indicates whether the financial institution (i) participated in both the AQR and stress test; (ii) is falling under the direct supervision of the SSM; (iii) has CDS data available; (iv) has stock futures data; and (v) is classified as G-SIB.

Notes: Austria, Belgium, France, Germany, Greece, Ireland, Italy, Malta, Netherlands, Portugal, Slovakia, Slovenia and Spain are euro area countries. Among these, Greece, Ireland, Italy, Portugal and Spain are peripheral euro area countries (i.e. GIIPS countries). Denmark, Hungary, Poland, Sweden and United Kingdom are EU but non-euro area countries. Norway is the only non-EU country.

Sample sizes, for both the CDS and stock market, are in line with recent banking literature (e.g. Sahin and de Haan, 2016; Carboni et al., 2017; Sclip et al., 2019). These papers do not use stock futures data. 
Table 3: Key-event dates

\begin{tabular}{|c|c|c|c|}
\hline \# & Date & Type & Description \\
\hline 1 & $12 / 09 / 2012$ & Supervision & $\begin{array}{l}\text { ECB welcomes Commission's proposal for a single supervisory } \\
\text { mechanism }\end{array}$ \\
\hline 2 & $13 / 12 / 2012$ & Supervision & ECB President Mario Draghi welcomes the agreement on the SSM \\
\hline 3 & $12 / 09 / 2013$ & Supervision & $\begin{array}{l}\text { ECB welcomes European Parliament vote to create single } \\
\text { supervisory mechanism }\end{array}$ \\
\hline 4 & $23 / 10 / 2013$ & $\begin{array}{l}\text { Comprehensive } \\
\text { Assessment }\end{array}$ & $\begin{array}{l}\text { ECB starts comprehensive assessment in advance of supervisory } \\
\text { role }\end{array}$ \\
\hline 5 & $08 / 11 / 2013$ & Resolution & $\begin{array}{l}\text { ECB publishes its opinion on the Single Resolution Mechanism } \\
\text { (SRM) }\end{array}$ \\
\hline 6 & 03/02/2014 & $\begin{array}{l}\text { Comprehensive } \\
\text { Assessment }\end{array}$ & $\begin{array}{l}\text { ECB makes progress with asset quality review, and confirms stress } \\
\text { test parameters for comprehensive assessment }\end{array}$ \\
\hline 7 & 07/02/2014 & Supervision & $\begin{array}{l}\text { ECB launches public consultation on draft ECB SSM Framework } \\
\text { Regulation }\end{array}$ \\
\hline 8 & $11 / 03 / 2014$ & $\begin{array}{l}\text { Comprehensive } \\
\text { Assessment }\end{array}$ & ECB publishes manual for asset quality review \\
\hline 9 & 20/03/2014 & Resolution & Statement of the ECB on SRM agreement \\
\hline 10 & $25 / 04 / 2014$ & Supervision & ECB publishes SSM Framework Regulation \\
\hline 11 & 29/04/2014 & $\begin{array}{l}\text { Comprehensive } \\
\text { Assessment }\end{array}$ & $\begin{array}{l}\text { ECB to give banks six to nine months to cover capital shortfalls } \\
\text { following comprehensive assessment }\end{array}$ \\
\hline 12 & $17 / 07 / 2014$ & $\begin{array}{l}\text { Comprehensive } \\
\text { Assessment }\end{array}$ & ECB publishes disclosure process for comprehensive assessment \\
\hline 13 & 08/08/2014 & $\begin{array}{l}\text { Comprehensive } \\
\text { Assessment }\end{array}$ & ECB publishes Comprehensive Assessment Stress Test Manual \\
\hline 14 & 04/09/2014 & $\begin{array}{l}\text { Comprehensive } \\
\text { Assessment }\end{array}$ & ECB publishes final list of significant credit institutions \\
\hline 15 & $27 / 10 / 2014$ & $\begin{array}{l}\text { Comprehensive } \\
\text { Assessment }\end{array}$ & ECB's in-depth review shows banks need to take further action \\
\hline 16 & $30 / 10 / 2014$ & Supervision & ECB publishes Regulation on supervisory fees \\
\hline 17 & 04/11/2014 & Supervision & ECB assumes responsibility for euro area banking supervision \\
\hline
\end{tabular}

Note: Since 26 October 2014, the date of publication of the CA outcomes, was a Sunday, the day considered as event date is the following trading day $(27 / 10 / 14)$.

Press releases on supervision matters and associated issues are usually published in the morning at 10:00 CET, although there is no stated fixed rule on the timing.

ECB's press releases can be found at https://www.ecb.europa.eu/press/html/index.en.html. 
Table 4: Bank-specific variables included in the multivariate analysis

\begin{tabular}{|c|c|c|c|c|}
\hline \multirow[t]{2}{*}{ Label } & \multirow[t]{2}{*}{ Variable } & \multirow[t]{2}{*}{ Indicator } & \multicolumn{2}{|c|}{ Expected impact } \\
\hline & & & CDS market & $\begin{array}{c}\text { Stock \& } \\
\text { stock futures }\end{array}$ \\
\hline CAR $(-1,1)$ & Cumulative Abnormal Return (\%) (bps) & Dep. Var. & & \\
\hline TIER1_RATIO & TIER 1 Capital to Risk-weighted Assets (\%) & Capitalization & - & $+/=$ \\
\hline NPL & NPLs to Gross Loans (\%) & Asset Quality & + & - \\
\hline TOT_ASSET & Total Assets (Ln) & Size & + & - \\
\hline ST_FUND & Deposit and Short Term Funding to Total Assets (\%) & Funding Structure & - & + \\
\hline CET1 & Common Equity Tier 1 Ratio (\%) & Capitalization & - & $+/=$ \\
\hline LOAN_TA & Net Loans to Total Assets (\%) & Business Model & - & + \\
\hline LEVERAGE_T & Total Assets to Total Equity - Ordinary measure (\%) & Capitalization & - & $+/=$ \\
\hline INTEREST & Interest Income to Average Earning Assets (\%) & Profitability & - & + \\
\hline NON_INTEREST & Non-Interest Income to Gross Revenues (\%) & Diversification & - & + \\
\hline RWA_TA & Risk-weighted Assets to Total Assets (\%) & Ex-ante Risk Taking & + & - \\
\hline
\end{tabular}

Note: The table presents the entire set of bank-level explanatory variables considered in the multivariate analysis, as well as the dependent variable (bank CAR computed over a 3-day event window around each announcement). It reports the definition and the bank characteristic which is being captured. 
Table 5: Descriptive statistics

\begin{tabular}{|c|c|c|c|c|c|c|c|c|}
\hline \multicolumn{9}{|c|}{ Panel A - CDS market } \\
\hline VARIABLES & Obs. & Min & Max & Mean & Median & Std.Dev. & Kurtosis & Skewness \\
\hline CAR $(-1,1)$ & 561 & -32.66 & 16.11 & -0.31 & 0.11 & 6.71 & 10.11 & -1.75 \\
\hline TIER1_RATIO & 525 & 7.38 & 22.43 & 13.08 & 12.33 & 3.00 & 4.95 & 1.28 \\
\hline NPL & 561 & 0.47 & 38.59 & 9.66 & 6.09 & 8.73 & 4.59 & 1.47 \\
\hline TOT_ASSET & 561 & 10.46 & 14.59 & 12.74 & 12.61 & 1.25 & 1.82 & -0.21 \\
\hline ST_FUND & 561 & 37.01 & 88.45 & 58.42 & 58.03 & 11.30 & 2.81 & 0.38 \\
\hline CET1 & 537 & 8.38 & 21.01 & 12.29 & 11.70 & 2.51 & 6.34 & 1.66 \\
\hline LOAN_TA & 561 & 19.63 & 74.04 & 51.96 & 55.74 & 15.04 & 2.49 & -0.69 \\
\hline LEVERAGE_T & 561 & 2.68 & 11.27 & 5.99 & 5.90 & 1.90 & 3.39 & 0.74 \\
\hline INTEREST & 561 & 1.35 & 5.85 & 2.99 & 2.87 & 1.06 & 3.50 & 0.89 \\
\hline NON_INTEREST & 561 & 7.76 & 60.40 & 37.37 & 38.57 & 11.80 & 2.48 & -0.34 \\
\hline RWA_TA & 544 & 17.06 & 83.37 & 40.99 & 41.55 & 14.66 & 3.64 & 0.66 \\
\hline \multicolumn{9}{|c|}{ Panel B - Stock and stock futures markets } \\
\hline VARIABLES & Obs. & Min & Max & Mean & Median & Std.Dev. & Kurtosis & Skewness \\
\hline CAR $(-1,1)$ & 850 & -14.58 & 12.35 & 0.01 & 0.13 & 3.60 & 7.17 & -0.41 \\
\hline TIER1_RATIO & 720 & 7.59 & 23.30 & 13.32 & 12.33 & 3.24 & 4.43 & 1.12 \\
\hline NPL & 850 & 0.47 & 44.89 & 11.43 & 7.49 & 10.10 & 5.03 & 1.52 \\
\hline TOT_ASSET & 850 & 8.38 & 14.59 & 11.98 & 11.90 & 1.59 & 2.24 & -0.14 \\
\hline ST_FUND & 850 & 37.01 & 88.45 & 62.25 & 62.30 & 13.21 & 2.01 & 0.03 \\
\hline CET1 & 785 & 5.09 & 21.01 & 12.46 & 11.75 & 2.83 & 4.05 & 0.75 \\
\hline LOAN_TA & 850 & 19.63 & 74.69 & 54.68 & 56.77 & 13.91 & 3.13 & -0.86 \\
\hline LEVERAGE_T & 850 & 1.27 & 16.03 & 6.70 & 6.38 & 2.79 & 4.55 & 1.08 \\
\hline INTEREST & 850 & 1.36 & 10.49 & 3.38 & 3.01 & 1.50 & 11.21 & 2.33 \\
\hline NON_INTEREST & 850 & 0.12 & 176.15 & 38.62 & 38.57 & 20.37 & 29.87 & 4.17 \\
\hline RWA_TA & 809 & 17.06 & 83.37 & 45.29 & 46.31 & 15.64 & 2.69 & 0.24 \\
\hline
\end{tabular}

Description: The table reports the descriptive statistics on both the dependent variable and bank explanatory variables. All variables are winsorized at the $1^{\text {st }}$ and $99^{\text {th }}$ percentiles. Obs. refers to the number of observations, which potentially differs to numbers reported in the tables for the multivariate analysis (Tables 12 and 13) due to differing sub-samples in different estimations and/or because of missing observations for some explanatory variables for some banks. TOT_ASSET is the natural logarithm of total assets. Sample period: 2012-2014. 
Table 6: CDS market reaction to the key BU announcements

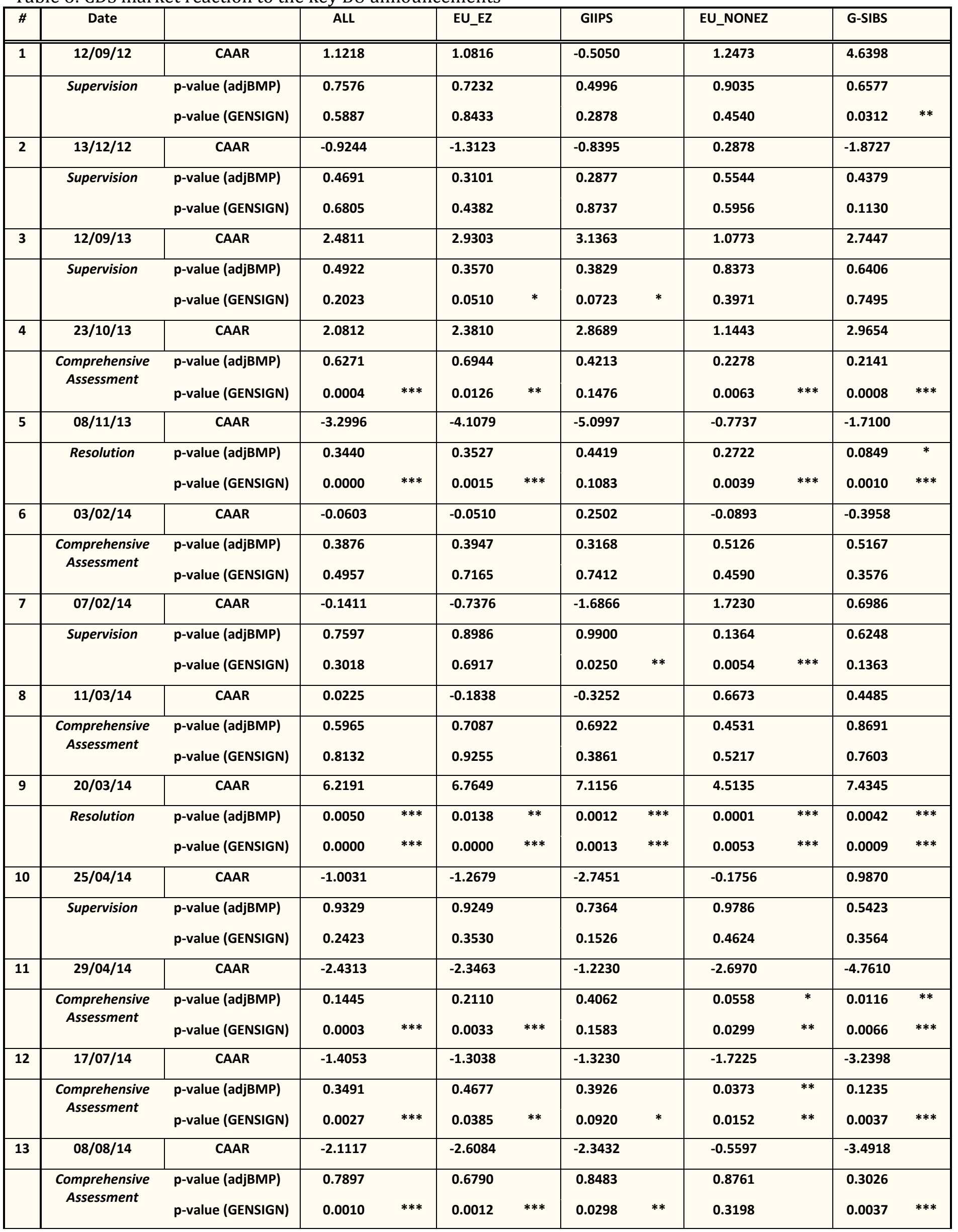




\begin{tabular}{|c|c|c|c|c|c|c|c|c|c|c|c|c|}
\hline 14 & $04 / 09 / 14$ & CAAR & 0.6974 & & 0.5283 & & 1.0726 & & 1.2258 & & -0.4369 & \\
\hline & $\begin{array}{c}\text { Comprehensive } \\
\text { Assessment }\end{array}$ & $\begin{array}{l}\text { p-value (adjBMP) } \\
\text { p-value (GENSIGN) }\end{array}$ & $\begin{array}{l}0.6997 \\
0.8159\end{array}$ & & $\begin{array}{l}0.8424 \\
0.7265\end{array}$ & & $\begin{array}{l}0.7492 \\
0.9383\end{array}$ & & $\begin{array}{l}0.4571 \\
0.2797\end{array}$ & & $\begin{array}{l}0.9988 \\
0.2696\end{array}$ & \\
\hline \multirow[t]{2}{*}{15} & $27 / 10 / 14$ & CAAR & -3.2008 & & -3.8050 & & -4.8887 & & -1.3127 & & -0.7366 & \\
\hline & $\begin{array}{c}\text { Comprehensive } \\
\text { Assessment }\end{array}$ & $\begin{array}{l}\text { p-value (adjBMP) } \\
\text { p-value (GENSIGN) }\end{array}$ & $\begin{array}{l}0.3814 \\
0.0000\end{array}$ & $* * *$ & $\begin{array}{l}0.4077 \\
0.0001\end{array}$ & $* * *$ & $\begin{array}{l}0.3408 \\
0.0004\end{array}$ & $* * *$ & $\begin{array}{l}0.1852 \\
0.0150\end{array}$ & $* *$ & $\begin{array}{l}0.5488 \\
0.0216\end{array}$ & $* *$ \\
\hline \multirow[t]{2}{*}{16} & $30 / 10 / 14$ & CAAR & 2.9913 & & 3.8121 & & 4.9821 & & 0.4265 & & 2.5274 & \\
\hline & Supervision & $\begin{array}{l}\text { p-value (adjBMP) } \\
\text { p-value (GENSIGN) }\end{array}$ & $\begin{array}{l}0.7029 \\
0.1773\end{array}$ & & $\begin{array}{l}0.7215 \\
0.0841\end{array}$ & $*$ & $\begin{array}{l}0.7462 \\
0.2982\end{array}$ & & $\begin{array}{l}0.6755 \\
0.7633\end{array}$ & & $\begin{array}{l}0.3326 \\
0.0119\end{array}$ & $* *$ \\
\hline \multirow[t]{2}{*}{17} & $04 / 11 / 14$ & CAAR & -2.0983 & & -2.9666 & & -3.3491 & & 0.6151 & & 0.5505 & \\
\hline & Supervision & $\begin{array}{l}\text { p-value (adjBMP) } \\
\text { p-value (GENSIGN) }\end{array}$ & $\begin{array}{l}0.7737 \\
0.9713\end{array}$ & & $\begin{array}{l}0.6994 \\
0.7792\end{array}$ & & $\begin{array}{l}0.7511 \\
0.1279\end{array}$ & & $\begin{array}{l}0.6008 \\
0.6758\end{array}$ & & $\begin{array}{l}0.7388 \\
0.1840\end{array}$ & \\
\hline
\end{tabular}

Description: The table reports the CAARs in the CDS market (in bps) in response to the key announcements on the BU. It indicates whether the event is related to the supervision, resolution or CA. It shows the CAARs for (i) the entire sample of banks (ALL); (ii) banks located in euro area countries (EU_EZ); (iii) banks located in euro area peripheral countries (GIIPS); (iv) banks located in EU non-euro area countries (EU_NONEZ); and (v) G-SIBs. Significance is tested according to the adjusted version of the Boehmer et al. (1991) test (adjBMP) by Kolari and Pynnönen (2010) and the generalized sign test by Cowan (1992) (GENSIGN).

Note: $^{* *}$ significant at the $1 \%$ level; ${ }^{* *}$ significant at the $5 \%$ level; * significant at the $10 \%$ level. 
Table 7: Aggregate CAARs (CDS market)

\begin{tabular}{|c|c|c|c|c|c|}
\hline Panel A - Aggregate CAARs & ALL & EU_EZ & GIIPS & EU_NONEZ & G-SIBS \\
\hline \hline Type of event & 2.43 & 1.54 & -1.01 & 5.20 & 10.28 \\
\hline Supervision & -6.41 & -7.39 & -5.91 & -3.34 & 3.74 \\
\hline Comprehensive Assessment & 2.92 & 2.66 & 2.02 & 5.72 \\
\hline Resolution & & & & EU_NONEZ & G-SIBS \\
\hline Panel B - Significant aggregate CAARs & ALL & EU_EZ & GIIPS & 1.72 & 7.17 \\
\hline Type of event & & 6.74 & 1.45 & -4.59 & -9.26 \\
\hline Supervision & -7.07 & -7.68 & -8.55 & 7.12 & 3.74 \\
\hline
\end{tabular}

Description: The table reports the aggregate CAARs in the CDS market (in bps) for the entire sample and the bank sub-groups. The event dates are grouped on the basis of their relevance in terms of (i) bank supervision; (ii) ECB's CA; and (iii) bank resolution. The figures are the outcome of an aggregation across events of the same nature. Significance is tested according to the adjusted version of the Boehmer et al. (1991) test by Kolari and Pynnönen (2010) and the generalized sign test by Cowan (1992).

Note: Panel A reports the aggregate data, based on Table 6, resulting from the sum of the coefficients associated with events on the same theme. In a similar way, Panel B reports only the significant aggregate figures. 
Table 8: Stock market reaction to the key BU announcements

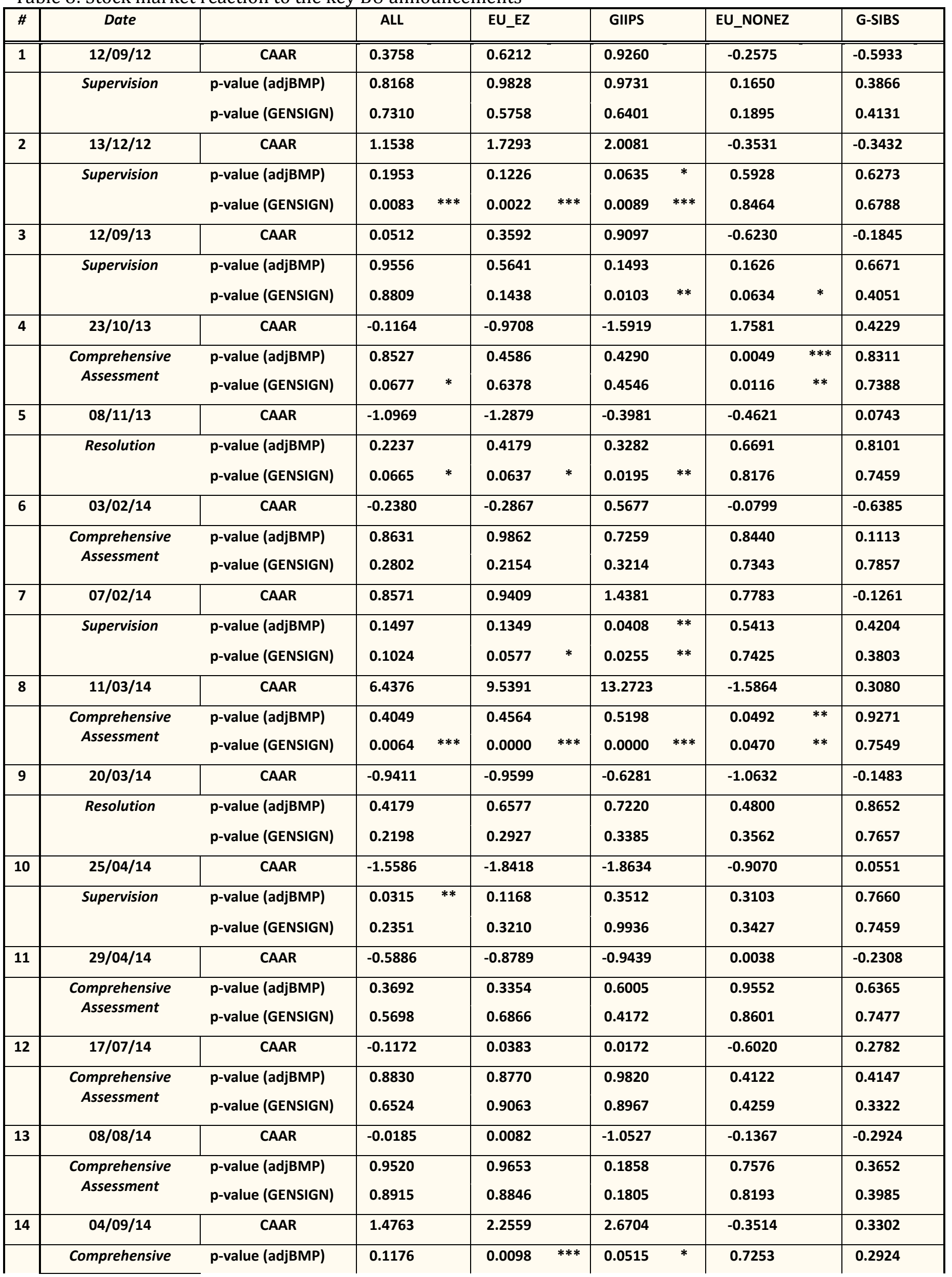




\begin{tabular}{|c|c|c|c|c|c|c|c|c|c|c|c|}
\hline & Assessment & p-value (GENSIGN) & 0.0037 & $* * *$ & 0.0000 & $* * *$ & 0.0001 & $* * *$ & 0.1449 & & 0.1248 \\
\hline \multirow[t]{2}{*}{15} & $27 / 10 / 14$ & CAAR & 0.1297 & & 0.1082 & & -0.7297 & & 0.0591 & & 0.2519 \\
\hline & $\begin{array}{c}\text { Comprehensive } \\
\text { Assessment }\end{array}$ & $\begin{array}{l}\text { p-value (adjBMP) } \\
\text { p-value (GENSIGN) }\end{array}$ & $\begin{array}{l}0.1000 \\
0.3949\end{array}$ & & $\begin{array}{l}0.1170 \\
0.0910\end{array}$ & * & $\begin{array}{l}0.5322 \\
0.8188\end{array}$ & & $\begin{array}{l}0.8570 \\
0.1555\end{array}$ & & $\begin{array}{l}0.6119 \\
0.7228\end{array}$ \\
\hline \multirow[t]{2}{*}{16} & $30 / 10 / 14$ & CAAR & -2.6003 & & -4.4766 & & -6.3840 & & 2.5211 & & 0.4629 \\
\hline & Supervision & $\begin{array}{l}\text { p-value (adjBMP) } \\
\text { p-value (GENSIGN) }\end{array}$ & $\begin{array}{l}0.1634 \\
0.0237\end{array}$ & $* *$ & $\begin{array}{l}0.0006 \\
0.0000\end{array}$ & $\begin{array}{l}* * * \\
* * *\end{array}$ & $\begin{array}{l}0.0016 \\
0.0000\end{array}$ & $\begin{array}{l}* * * \\
* * *\end{array}$ & $\begin{array}{l}0.0001 \\
0.0026\end{array}$ & $\begin{array}{l}* * * \\
* * *\end{array}$ & $\begin{array}{l}0.9455 \\
0.1451\end{array}$ \\
\hline \multirow[t]{2}{*}{17} & $04 / 11 / 14$ & CAAR & 0.2314 & & 0.3536 & & 0.0485 & & -0.1039 & & 0.2954 \\
\hline & Supervision & $\begin{array}{l}\text { p-value (adjBMP) } \\
\text { p-value (GENSIGN) }\end{array}$ & $\begin{array}{l}0.9955 \\
0.4137\end{array}$ & & $\begin{array}{l}0.9917 \\
0.5134\end{array}$ & & $\begin{array}{l}0.4950 \\
0.5134\end{array}$ & & $\begin{array}{l}0.9221 \\
0.8109\end{array}$ & & $\begin{array}{l}0.2982 \\
0.3405\end{array}$ \\
\hline
\end{tabular}

Description: The table reports the CAARs in the stock market (in \%) in response to the key announcement on the BU. It indicates if the event is related to the supervision, resolution or CA. It shows the CAARs for (i) the entire sample of banks (ALL); (ii) banks located in euro area countries (EU_EZ); (iii) banks located in euro area peripheral countries (GIIPS); (iv) banks located in EU non-euro area countries (EU_NONEZ); and (v) G-SIBs. Significance is tested according to the adjusted version of the Boehmer et al. (1991) test (adjBMP) by Kolari and Pynnönen (2010) and the generalized sign test by Cowan (1992) (GENSIGN).

Note: ${ }^{* *}$ significant at the $1 \%$ level; ${ }^{* *}$ significant at the $5 \%$ level; ${ }^{*}$ significant at the $10 \%$ level. 
Table 9: Aggregate CAARs (stock market)

\begin{tabular}{|c|c|c|c|c|c|}
\hline \multicolumn{6}{|l|}{ Panel A - Aggregate CAARs } \\
\hline Type of event & ALL & EU_EZ & GIIPS & EU_NONEZ & G-SIBS \\
\hline Supervision & -1.49 & -2.31 & -2.92 & 1.05 & -0.43 \\
\hline Comprehensive Assessment & 6.96 & 9.81 & 12.21 & -0.94 & 0.43 \\
\hline Resolution & -2.04 & -2.25 & -1.03 & -1.53 & -0.07 \\
\hline \multicolumn{6}{|c|}{ Panel B - Significant aggregate CAARs } \\
\hline Type of event & ALL & EU_EZ & GIIPS & EU_NONEZ & G-SIBS \\
\hline Supervision & -3.01 & -1.81 & -2.03 & 1.90 & \\
\hline Comprehensive Assessment & 7.80 & 11.90 & 15.94 & 0.17 & \\
\hline Resolution & -1.10 & -1.29 & -0.40 & & \\
\hline
\end{tabular}

Description: The table reports the aggregate CAARs in the stock market (in \%) for the entire sample and the bank sub-groups. The event dates are grouped on the basis of their relevance in terms of (i) bank supervision; (ii) ECB's CA; and (iii) bank resolution. The figures are the outcome of an aggregation across events of the same nature. Significance is tested according to the adjusted version of the Boehmer et al. (1991) test by Kolari and Pynnönen (2010) and the generalized sign test by Cowan (1992).

Note: Panel A reports the aggregate data, based on Table 6, resulting from the sum of the coefficients associated with events on the same theme. In a similar way, Panel B reports only the significant aggregate figures. 
Table 10: Stock futures market reaction to the key BU announcements

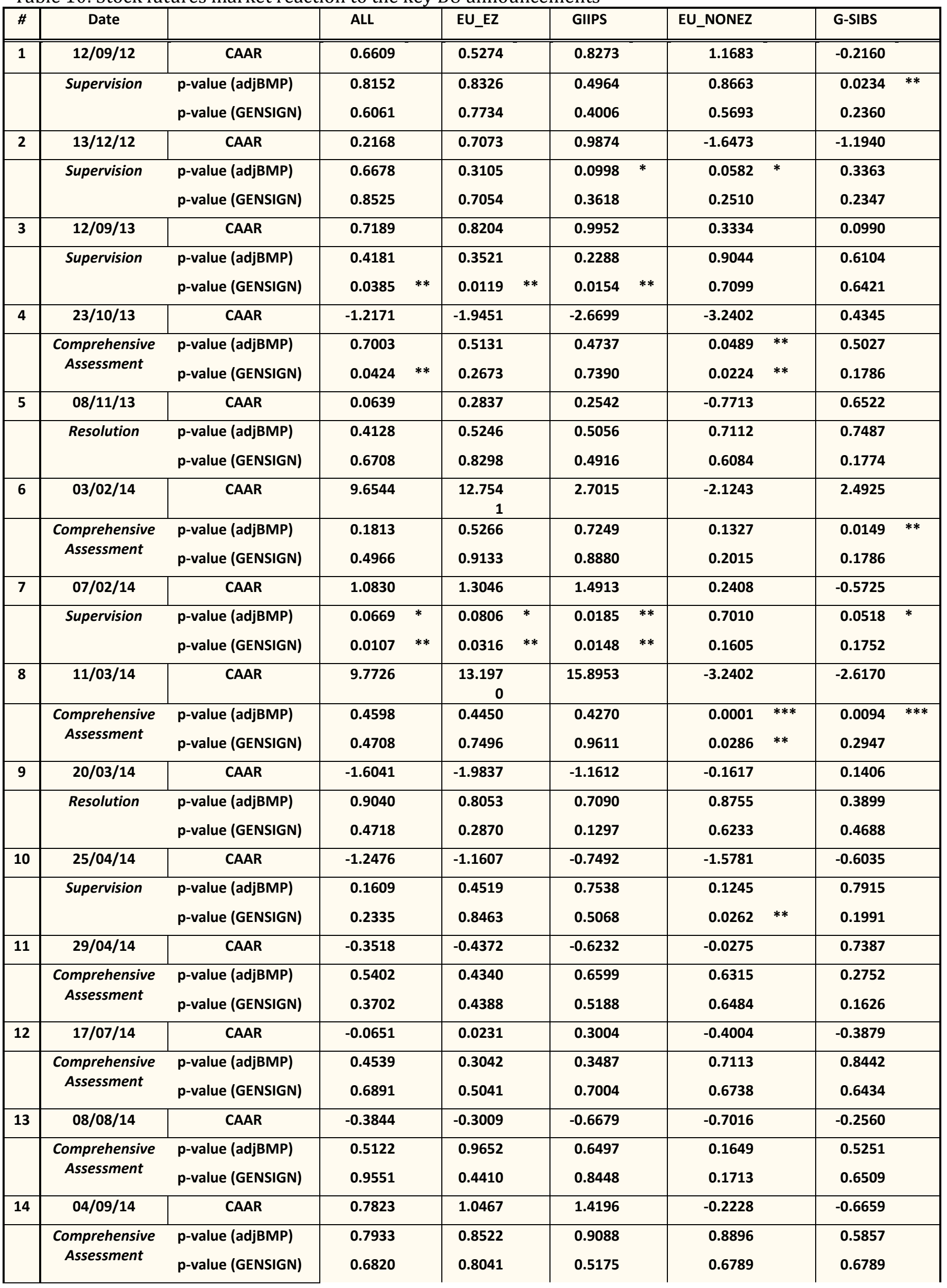




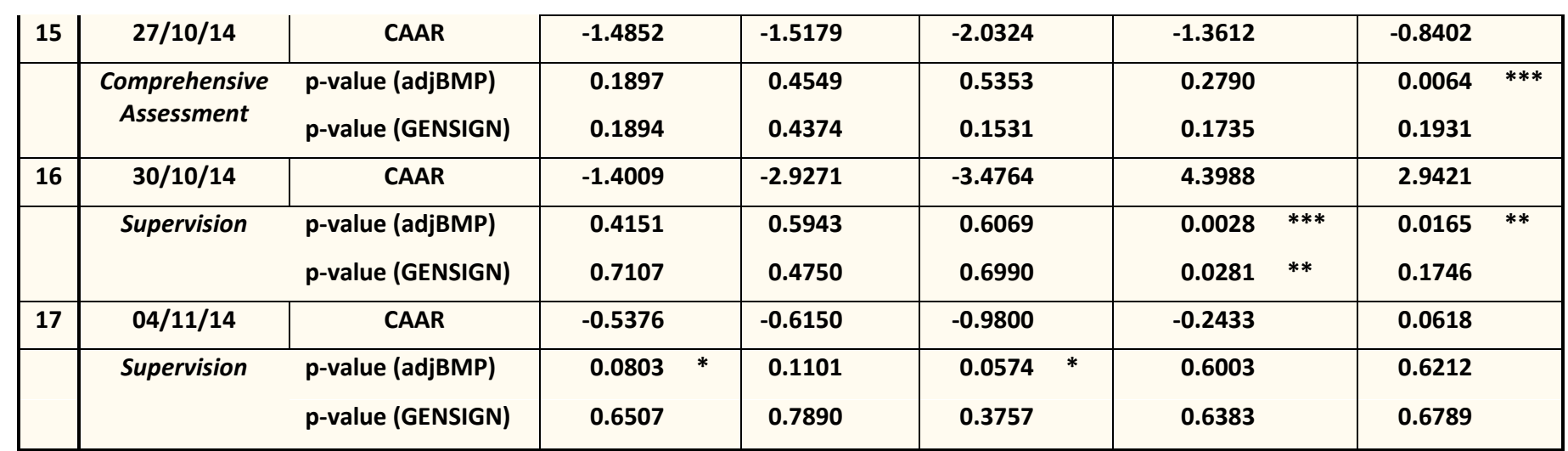

Description: The table reports the CAARs in the stock futures market (in \%) in response to the key announcement on the BU. It indicates if the event is related to the supervision, resolution or CA. It shows the CAARs for (i) the entire sample of banks (ALL); (ii) banks located in euro area countries (EU_EZ); (iii) banks located in euro area peripheral countries (GIIPS); (iv) banks located in EU non-euro area countries (EU_NONEZ); and (v) G-SIBs. Significance is tested according to the adjusted version of the Boehmer et al. (1991) test (adjBMP) by Kolari and Pynnönen (2010) and the generalized sign test by Cowan (1992) (GENSIGN). Note: ${ }^{* * *}$ significant at the $1 \%$ level; ${ }^{* *}$ significant at the $5 \%$ level; * significant at the $10 \%$ level. 
Table 11: Aggregate CAARs (stock futures market)

\begin{tabular}{|c|c|c|c|c|c|}
\hline Panel A - Aggregate CAARs & ALL & EU_EZ & GIIPS & EU_NONEZ & G-SIBS \\
\hline \hline Type of event & 0.03 & -0.73 & 0.08 & 2.92 & 0.46 \\
\hline Supervision & 16.71 & 22.82 & 14.32 & -11.32 & -1.10 \\
\hline Comprehensive Assessment & -1.54 & -1.70 & -0.91 & -0.93 & 0.79 \\
\hline Resolution & & & \\
\hline Panel B Significant aggregate CAARs & ALL & EU_EZ & GIIPS & EU_NONEZ & G-SIBS \\
\hline \begin{tabular}{|l} 
Type of event \\
Supervision
\end{tabular} & 1.26 & 2.12 & 2.49 & 1.17 & 2.15 \\
\hline \hline Comprehensive Assessment & -1.22 & & & -6.48 & -0.96 \\
\hline Resolution & & & & & \\
\hline
\end{tabular}

Description: The table reports the aggregate CAARs in the stock futures market (in \%) for the entire sample and the bank subgroups. The event dates are grouped on the basis of their relevance in terms of (i) bank supervision; (ii) ECB's CA; and (iii) bank resolution. The figures are the outcome of an aggregation across events of the same nature. Significance is tested according to the adjusted version of the Boehmer et al. (1991) test by Kolari and Pynnönen (2010) and the generalized sign test by Cowan (1992).

Note: Panel A reports the aggregate data, based on Table 6, resulting from the sum of the coefficients associated with events on the same theme. In a similar way, Panel B reports only the significant aggregate figures. 
Table 12: Determinants of CARs (CDS market)

\begin{tabular}{|c|c|c|c|c|c|}
\hline VARIABLES & & & & & \\
\hline & ALL & EU_EZ & GIIPS & EU_NONEZ & G-SIBS \\
\hline \multirow[t]{2}{*}{ TIER1_RATIO } & -0.023 & -0.118 & -1.881 & -0.167 & $1.726^{* *}$ \\
\hline & $(0.188)$ & $(0.422)$ & (1.140) & $(0.165)$ & (0.679) \\
\hline \multirow[t]{2}{*}{ NPL } & -0.050 & -0.098 & -0.311 & $1.100^{* *}$ & $3.163^{* * *}$ \\
\hline & $(0.184)$ & $(0.204)$ & $(0.207)$ & $(0.395)$ & (0.649) \\
\hline \multirow[t]{2}{*}{ TOT_ASSET } & -14.218 & -17.789 & -15.032 & -6.662 & 15.590 \\
\hline & (8.828) & (11.116) & (12.420) & (7.083) & (12.947) \\
\hline \multirow[t]{2}{*}{ ST_FUND } & $0.272^{* *}$ & 0.286 & 0.131 & 0.128 & $-0.355^{* *}$ \\
\hline & (0.124) & (0.186) & $(0.254)$ & (0.141) & $(0.140)$ \\
\hline \multirow[t]{2}{*}{ LOAN_TA } & $-0.362^{*}$ & -0.382 & 0.325 & 0.009 & 0.047 \\
\hline & $(0.207)$ & $(0.265)$ & $(0.443)$ & $(0.177)$ & (0.481) \\
\hline \multirow[t]{2}{*}{ INTEREST } & 0.597 & 0.366 & -3.687 & $-3.914^{* *}$ & -3.010 \\
\hline & $(0.856)$ & (1.109) & (2.247) & (1.568) & (4.176) \\
\hline \multirow[t]{2}{*}{ NON_INTEREST } & 0.085 & 0.068 & $0.310^{*}$ & $-0.097^{* * *}$ & $-0.475 * * *$ \\
\hline & (0.068) & (0.159) & (0.171) & $(0.033)$ & $(0.145)$ \\
\hline \multirow[t]{2}{*}{ RWA_TA } & -0.001 & 0.003 & $0.239^{*}$ & $-0.070^{*}$ & 0.505 \\
\hline & (0.109) & (0.146) & $(0.135)$ & $(0.040)$ & $(0.455)$ \\
\hline Obs. & 520 & 384 & 248 & 136 & 170 \\
\hline R-squared & 0.300 & 0.313 & 0.369 & 0.456 & 0.625 \\
\hline
\end{tabular}

Description: The table reports the results for the regression model presented in Section 4.2, for the entire sample and the bank sub-groups, related to the CDS market. The dependent variable is the bank CAR calculated over a 3-day event window. Robust standard errors are clustered at bank-year level (in parentheses).

Note: ${ }^{* * *}$ significant at the $1 \%$ level; ${ }^{* *}$ significant at the $5 \%$ level; ${ }^{*}$ significant at the $10 \%$ level. 
Table 13: Determinants of CARs (stock market)

\begin{tabular}{|c|c|c|c|c|c|}
\hline VARIABLES & & & & & \\
\hline \multirow{3}{*}{ TIER1_RATIO } & ALL & EU_EZ & PIIGS & EU_NONEZ & G-SIBS \\
\hline & $0.200 * *$ & $0.385^{* * *}$ & 0.311 & -0.088 & -0.034 \\
\hline & (0.098) & $(0.146)$ & $(0.257)$ & $(0.073)$ & $(0.150)$ \\
\hline \multirow[t]{2}{*}{ NPL } & -0.077 & -0.015 & -0.063 & -0.108 & $0.667 * * *$ \\
\hline & (0.059) & $(0.080)$ & $(0.102)$ & $(0.183)$ & (0.209) \\
\hline \multirow[t]{2}{*}{ TOT_ASSET } & -2.735 & 0.502 & -1.833 & $-5.595^{* *}$ & 4.800 \\
\hline & (1.957) & (3.528) & (4.981) & (2.518) & (4.729) \\
\hline \multirow[t]{2}{*}{ ST_FUND } & -0.054 & -0.071 & -0.087 & 0.053 & -0.075 \\
\hline & $(0.036)$ & $(0.046)$ & $(0.063)$ & $(0.055)$ & $(0.067)$ \\
\hline \multirow[t]{2}{*}{ LOAN_TA } & 0.053 & 0.117 & 0.032 & $0.209 * *$ & $0.595 * * *$ \\
\hline & (0.049) & $(0.074)$ & $(0.081)$ & $(0.082)$ & $(0.206)$ \\
\hline \multirow[t]{2}{*}{ INTEREST } & 0.319 & 0.765 & 0.496 & $-0.979 *$ & $-3.469 * *$ \\
\hline & $(0.579)$ & $(0.593)$ & (0.779) & $(0.502)$ & (1.453) \\
\hline \multirow[t]{2}{*}{ NON_INTEREST } & $0.044 *$ & 0.033 & -0.022 & $0.102 * * *$ & -0.046 \\
\hline & $(0.025)$ & $(0.028)$ & $(0.068)$ & $(0.030)$ & $(0.066)$ \\
\hline \multirow[t]{2}{*}{ RWA_TA } & 0.028 & 0.031 & 0.047 & $-0.087^{* *}$ & -0.084 \\
\hline & $(0.043)$ & $(0.046)$ & $(0.054)$ & $(0.041)$ & $(0.066)$ \\
\hline Obs. & 703 & 501 & 326 & 185 & 170 \\
\hline R-squared & 0.142 & 0.243 & 0.344 & 0.343 & 0.118 \\
\hline
\end{tabular}

Description: The table reports the results for the regression model presented in Section 4.2, for the entire sample and the bank sub-groups, related to the stock market. The dependent variable is the bank CAR calculated over a 3-day event window. Robust standard errors are clustered at bank-year level (in parentheses).

Note: ${ }^{* * *}$ significant at the $1 \%$ level; ${ }^{* *}$ significant at the $5 \%$ level; ${ }^{*}$ significant at the $10 \%$ level. 
Table 14: CDS market reaction to the key BU announcements (1-day event window)

\begin{tabular}{|c|c|c|c|c|c|c|c|c|c|c|c|c|}
\hline$\#$ & Date & & ALL & & EU_EZ & & GIIPS & & EU_NONEZ & & G-SIBS & \\
\hline \multirow[t]{2}{*}{1} & $12 / 09 / 12$ & CAAR & -1.4798 & & -1.2840 & & -1.4220 & & -2.0917 & & -1.2223 & \\
\hline & Supervision & $\begin{array}{l}\text { p-value (adjBMP) } \\
\text { p-value (GENSIGN) }\end{array}$ & $\begin{array}{l}0.6771 \\
0.1216\end{array}$ & & $\begin{array}{l}0.8427 \\
0.3162\end{array}$ & & $\begin{array}{l}0.9251 \\
0.5736\end{array}$ & & $\begin{array}{l}0.2890 \\
0.1698\end{array}$ & & $\begin{array}{l}0.6308 \\
0.3893\end{array}$ & \\
\hline \multirow[t]{2}{*}{2} & $13 / 12 / 12$ & CAAR & -0.0551 & & 0.0315 & & 0.5924 & & -0.3256 & & -1.4444 & \\
\hline & Supervision & $\begin{array}{l}\text { p-value (adjBMP) } \\
\text { p-value (GENSIGN) }\end{array}$ & $\begin{array}{l}0.6218 \\
0.9508\end{array}$ & & $\begin{array}{l}0.5240 \\
0.9761\end{array}$ & & $\begin{array}{l}0.7011 \\
0.7279\end{array}$ & & $\begin{array}{l}0.9776 \\
0.8589\end{array}$ & & $\begin{array}{l}0.4058 \\
0.3263\end{array}$ & \\
\hline \multirow[t]{2}{*}{3} & $12 / 09 / 13$ & CAAR & 1.7854 & & 1.8955 & & 2.1628 & & 1.4411 & & 1.6790 & \\
\hline & Supervision & $\begin{array}{l}\text { p-value (adjBMP) } \\
\text { p-value (GENSIGN) }\end{array}$ & $\begin{array}{l}0.0816 \\
0.0002\end{array}$ & $\begin{array}{c}* \\
* * *\end{array}$ & $\begin{array}{l}0.1468 \\
0.0058\end{array}$ & $* * *$ & $\begin{array}{l}0.1984 \\
0.0723\end{array}$ & $*$ & $\begin{array}{l}0.0020 \\
0.0071\end{array}$ & $\begin{array}{l}* * * \\
* * *\end{array}$ & $\begin{array}{l}0.1962 \\
0.0063\end{array}$ & $* * *$ \\
\hline \multirow[t]{2}{*}{4} & $23 / 10 / 13$ & CAAR & 1.1946 & & 1.3253 & & 1.5563 & & 0.7860 & & 0.9750 & \\
\hline & $\begin{array}{c}\text { Comprehensive } \\
\text { Assessment }\end{array}$ & $\begin{array}{l}\text { p-value (adjBMP) } \\
\text { p-value (GENSIGN) }\end{array}$ & $\begin{array}{l}0.0362 \\
0.0000\end{array}$ & $\begin{array}{l}* * \\
* * *\end{array}$ & $\begin{array}{l}0.0403 \\
0.0000\end{array}$ & $\begin{array}{l}* * \\
* * *\end{array}$ & $\begin{array}{l}0.0051 \\
0.0030\end{array}$ & $\begin{array}{l}* * * \\
* * *\end{array}$ & $\begin{array}{l}0.0190 \\
0.0063\end{array}$ & $\begin{array}{l}* * \\
* * *\end{array}$ & $\begin{array}{l}0.1821 \\
0.0008\end{array}$ & $* * *$ \\
\hline \multirow[t]{2}{*}{5} & $08 / 11 / 13$ & CAAR & -0.0273 & & -0.1427 & & -0.4018 & & 0.3335 & & 1.0078 & \\
\hline & Resolution & $\begin{array}{l}\text { p-value (adjBMP) } \\
\text { p-value (GENSIGN) }\end{array}$ & $\begin{array}{l}0.9325 \\
0.0016\end{array}$ & $* * *$ & $\begin{array}{l}0.9853 \\
0.0136\end{array}$ & $* *$ & $\begin{array}{l}0.9161 \\
0.0533\end{array}$ & $*$ & $\begin{array}{l}0.5219 \\
0.0393\end{array}$ & $* *$ & $\begin{array}{l}0.5942 \\
0.0063\end{array}$ & $* * *$ \\
\hline \multirow[t]{2}{*}{6} & $03 / 02 / 14$ & CAAR & -2.1836 & & -2.4976 & & -3.2468 & & -1.2024 & & -2.2827 & \\
\hline & $\begin{array}{c}\text { Comprehensive } \\
\text { Assessment }\end{array}$ & $\begin{array}{l}\text { p-value (adjBMP) } \\
\text { p-value (GENSIGN) }\end{array}$ & $\begin{array}{l}0.0554 \\
0.0000\end{array}$ & $\begin{array}{c}* \\
* * *\end{array}$ & $\begin{array}{l}0.0619 \\
0.0000\end{array}$ & $\begin{array}{c}* \\
* * *\end{array}$ & $\begin{array}{l}0.0732 \\
0.0013\end{array}$ & $\begin{array}{c}* \\
* * * \\
* * *\end{array}$ & $\begin{array}{l}0.1350 \\
0.0312\end{array}$ & $* *$ & $\begin{array}{l}0.0012 \\
0.0009\end{array}$ & $\begin{array}{l}* * * \\
* * *\end{array}$ \\
\hline \multirow[t]{2}{*}{7} & $07 / 02 / 14$ & CAAR & 1.4976 & & 1.4650 & & 1.7279 & & 1.5993 & & 1.6900 & \\
\hline & Supervision & $\begin{array}{l}\text { p-value (adjBMP) } \\
\text { p-value (GENSIGN) }\end{array}$ & $\begin{array}{l}0.0564 \\
0.0001\end{array}$ & $\begin{array}{c}* \\
* * *\end{array}$ & $\begin{array}{l}0.0529 \\
0.0012 \\
\end{array}$ & $\begin{array}{c}* \\
* * *\end{array}$ & $\begin{array}{l}0.0489 \\
0.0198 \\
\end{array}$ & $\begin{array}{l}* * \\
* *\end{array}$ & $\begin{array}{l}0.0557 \\
0.0378\end{array}$ & $\begin{array}{l}* \\
* *\end{array}$ & $\begin{array}{l}0.0592 \\
0.0010\end{array}$ & $\begin{array}{c}* * \\
* * *\end{array}$ \\
\hline \multirow[t]{2}{*}{8} & $11 / 03 / 14$ & CAAR & -1.5544 & & -1.8644 & & -2.4117 & & -0.5853 & & -1.2939 & \\
\hline & $\begin{array}{c}\text { Comprehensive } \\
\text { Assessment }\end{array}$ & $\begin{array}{l}\text { p-value (adjBMP) } \\
\text { p-value (GENSIGN) }\end{array}$ & $\begin{array}{l}0.2335 \\
0.0000\end{array}$ & $* * *$ & $\begin{array}{l}0.2606 \\
0.0000\end{array}$ & $* * *$ & $\begin{array}{l}0.3022 \\
0.0036\end{array}$ & $* * *$ & $\begin{array}{l}0.1808 \\
0.0038\end{array}$ & $* * *$ & $\begin{array}{l}0.1715 \\
0.0009\end{array}$ & $* * *$ \\
\hline \multirow[t]{2}{*}{9} & $20 / 03 / 14$ & CAAR & 7.5298 & & 8.2075 & & 8.3907 & & 5.4118 & & 9.6031 & \\
\hline & Resolution & $\begin{array}{l}\text { p-value (adjBMP) } \\
\text { p-value (GENSIGN) }\end{array}$ & $\begin{array}{l}0.0036 \\
0.0000\end{array}$ & $\begin{array}{l}* * * \\
* * *\end{array}$ & $\begin{array}{l}0.0097 \\
0.0000\end{array}$ & $\begin{array}{l}* * \\
* * *\end{array}$ & $\begin{array}{l}0.0027 \\
0.0013\end{array}$ & $\begin{array}{l}* * * \\
* * *\end{array}$ & $\begin{array}{l}0.0003 \\
0.0053\end{array}$ & $\begin{array}{l}* * * \\
* * *\end{array}$ & $\begin{array}{l}0.0013 \\
0.0009\end{array}$ & $\begin{array}{l}* * \\
* * *\end{array}$ \\
\hline \multirow[t]{2}{*}{10} & $25 / 04 / 14$ & CAAR & 1.2373 & & 1.5058 & & 1.3329 & & 0.3983 & & 1.5097 & \\
\hline & Supervision & $\begin{array}{l}\text { p-value (adjBMP) } \\
\text { p-value (GENSIGN) }\end{array}$ & $\begin{array}{l}0.2248 \\
0.0007\end{array}$ & $* * *$ & $\begin{array}{l}0.1736 \\
0.0019\end{array}$ & $* * *$ & $\begin{array}{l}0.3276 \\
0.0994\end{array}$ & $*$ & $\begin{array}{l}0.5738 \\
0.1656\end{array}$ & & $\begin{array}{l}0.4336 \\
0.1272\end{array}$ & \\
\hline \multirow[t]{2}{*}{11} & $29 / 04 / 14$ & CAAR & -0.3374 & & -0.2281 & & -0.0118 & & -0.6789 & & -0.9873 & \\
\hline & $\begin{array}{c}\text { Comprehensive } \\
\text { Assessment }\end{array}$ & $\begin{array}{l}\text { p-value (adjBMP) } \\
\text { p-value (GENSIGN) }\end{array}$ & $\begin{array}{l}0.4909 \\
0.0263\end{array}$ & $* *$ & $\begin{array}{l}0.6167 \\
0.1863\end{array}$ & & $\begin{array}{l}0.8876 \\
0.3690\end{array}$ & & $\begin{array}{l}0.3450 \\
0.0299\end{array}$ & $* *$ & $\begin{array}{l}0.2723 \\
0.0066\end{array}$ & $* * *$ \\
\hline \multirow[t]{2}{*}{12} & $17 / 07 / 14$ & CAAR & 3.5496 & & 4.2108 & & 4.7114 & & 1.4835 & & 3.3290 & \\
\hline & $\begin{array}{c}\text { Comprehensive } \\
\text { Assessment }\end{array}$ & $\begin{array}{l}\text { p-value (adjBMP) } \\
\text { p-value (GENSIGN) }\end{array}$ & $\begin{array}{l}0.0391 \\
0.0000\end{array}$ & $\begin{array}{l}* * \\
* * *\end{array}$ & $\begin{array}{l}0.0415 \\
0.0000\end{array}$ & $\begin{array}{l}* * \\
* * *\end{array}$ & $\begin{array}{l}0.0130 \\
0.0027\end{array}$ & $\begin{array}{l}* * \\
* * *\end{array}$ & $\begin{array}{l}0.0475 \\
0.0108\end{array}$ & $\begin{array}{l}* * \\
* *\end{array}$ & $\begin{array}{l}0.0125 \\
0.0017\end{array}$ & $\begin{array}{l}* * \\
* * *\end{array}$ \\
\hline \multirow[t]{2}{*}{13} & $08 / 08 / 14$ & CAAR & -2.7103 & & -3.4215 & & -4.1628 & & -0.4877 & & -2.0389 & \\
\hline & $\begin{array}{c}\text { Comprehensive } \\
\text { Assessment }\end{array}$ & $\begin{array}{l}\text { p-value (adjBMP) } \\
\text { p-value (GENSIGN) }\end{array}$ & $\begin{array}{l}0.5001 \\
0.0000\end{array}$ & $* * *$ & $\begin{array}{l}0.3368 \\
0.0000\end{array}$ & $* * *$ & $\begin{array}{l}0.4305 \\
0.0002\end{array}$ & $* * *$ & $\begin{array}{l}0.9626 \\
0.3198\end{array}$ & & $\begin{array}{l}0.0973 \\
0.0005\end{array}$ & $* * *$ \\
\hline
\end{tabular}




\begin{tabular}{|c|c|c|c|c|c|c|c|c|c|c|c|}
\hline 14 & 04/09/14 & CAAR & -0.3599 & & -0.2766 & & 0.1141 & -0.6200 & & -1.2332 & \\
\hline & $\begin{array}{c}\text { Comprehensive } \\
\text { Assessment }\end{array}$ & $\begin{array}{l}\text { p-value (adjBMP) } \\
\text { p-value (GENSIGN) }\end{array}$ & $\begin{array}{l}0.5537 \\
0.0095\end{array}$ & $* * *$ & $\begin{array}{l}0.7003 \\
0.1160\end{array}$ & & $\begin{array}{l}0.8908 \\
0.5509\end{array}$ & $\begin{array}{l}0.1923 \\
0.0131\end{array}$ & $* *$ & $\begin{array}{l}0.3750 \\
0.0208\end{array}$ & $* *$ \\
\hline \multirow[t]{2}{*}{15} & $27 / 10 / 14$ & CAAR & -0.7472 & & -0.9566 & & -1.1961 & -0.0928 & & 0.1700 & \\
\hline & $\begin{array}{c}\text { Comprehensive } \\
\text { Assessment }\end{array}$ & $\begin{array}{l}\text { p-value (adjBMP) } \\
\text { p-value (GENSIGN) }\end{array}$ & $\begin{array}{l}0.7222 \\
0.1657\end{array}$ & & $\begin{array}{l}0.6905 \\
0.3394\end{array}$ & & $\begin{array}{l}0.6363 \\
0.5786\end{array}$ & $\begin{array}{l}0.8692 \\
0.2611\end{array}$ & & $\begin{array}{l}0.9760 \\
0.1847\end{array}$ & \\
\hline \multirow[t]{2}{*}{16} & $30 / 10 / 14$ & CAAR & 0.9903 & & 0.9705 & & 0.5428 & 1.0523 & & 2.6410 & \\
\hline & Supervision & $\begin{array}{l}\text { p-value (adjBMP) } \\
\text { p-value (GENSIGN) }\end{array}$ & $\begin{array}{l}0.4443 \\
0.0019\end{array}$ & $* * *$ & $\begin{array}{l}0.5136 \\
0.0329\end{array}$ & $* *$ & $\begin{array}{l}0.7737 \\
0.2982\end{array}$ & $\begin{array}{l}0.3183 \\
0.0110\end{array}$ & $* *$ & $\begin{array}{l}0.1221 \\
0.0018\end{array}$ & $* * *$ \\
\hline \multirow[t]{2}{*}{17} & 04/11/14 & CAAR & 1.9200 & & 2.1638 & & 3.2107 & 1.1579 & & 0.7762 & \\
\hline & Supervision & $\begin{array}{l}\text { p-value (adjBMP) } \\
\text { p-value (GENSIGN) }\end{array}$ & $\begin{array}{l}0.5454 \\
0.0017\end{array}$ & $* * *$ & $\begin{array}{l}0.7059 \\
0.0310\end{array}$ & $* *$ & $\begin{array}{l}0.7344 \\
0.2912\end{array}$ & $\begin{array}{l}0.1947 \\
0.0107\end{array}$ & $* *$ & $\begin{array}{l}0.6373 \\
0.0112\end{array}$ & $* *$ \\
\hline
\end{tabular}

Description: The table reports the CAARs in the CDS market (in bps) in response to the key announcement on the BU. It indicates whether the event is related to the supervision, resolution or CA. It shows the CAARs for (i) the entire sample of banks (ALL); (ii) banks located in euro area countries (EU_EZ); (iii) banks located in euro area peripheral countries (GIIPS); (iv) banks located in EU non-euro area countries (EU_NONEZ); and (v) G-SIBs. Significance is tested according to the adjusted version of the Boehmer et al. (1991) test (adjBMP) by Kolari and Pynnönen (2010) and the generalized sign test by Cowan (1992) (GENSIGN).

Note: ${ }^{* * *}$ significant at the $1 \%$ level; ${ }^{* *}$ significant at the $5 \%$ level; * significant at the $10 \%$ level. 
Table 15: Stock market reaction to the key BU announcements (1-day event window)

\begin{tabular}{|c|c|c|c|c|c|c|c|c|c|c|c|}
\hline$\#$ & Date & & ALL & & EU_EZ & & GIIPS & & EU_NONEZ & & G-SIBS \\
\hline \multirow[t]{2}{*}{1} & $12 / 09 / 12$ & CAAR & 1.7239 & & 2.4520 & & 2.7911 & & -0.1567 & & -0.3718 \\
\hline & Supervision & $\begin{array}{l}\text { p-value (adjBMP) } \\
\text { p-value (GENSIGN) }\end{array}$ & $\begin{array}{l}0.1549 \\
0.4310\end{array}$ & & $\begin{array}{l}0.1594 \\
0.1188 \\
\end{array}$ & & $\begin{array}{l}0.1959 \\
0.0906\end{array}$ & $*$ & $\begin{array}{l}0.7541 \\
0.4490 \\
\end{array}$ & & $\begin{array}{l}0.3305 \\
0.1551 \\
\end{array}$ \\
\hline \multirow[t]{2}{*}{2} & $13 / 12 / 12$ & CAAR & 0.8591 & & 1.3634 & & 0.9276 & & -0.4588 & & -0.1654 \\
\hline & Supervision & $\begin{array}{l}\text { p-value (adjBMP) } \\
\text { p-value (GENSIGN) }\end{array}$ & $\begin{array}{l}0.2809 \\
0.0736 \\
\end{array}$ & $*$ & $\begin{array}{l}0.2017 \\
0.0007\end{array}$ & $* * *$ & $\begin{array}{l}0.1144 \\
0.0006\end{array}$ & $* * *$ & $\begin{array}{l}0.2059 \\
0.0631\end{array}$ & $*$ & $\begin{array}{l}0.7358 \\
0.6788 \\
\end{array}$ \\
\hline \multirow[t]{2}{*}{3} & $12 / 09 / 13$ & CAAR & 0.2310 & & 0.4267 & & 0.5943 & & -0.0759 & & -0.2514 \\
\hline & Supervision & $\begin{array}{l}\text { p-value (adjBMP) } \\
\text { p-value (GENSIGN) }\end{array}$ & $\begin{array}{l}0.5863 \\
0.6652 \\
\end{array}$ & & $\begin{array}{l}0.9145 \\
0.4266 \\
\end{array}$ & & $\begin{array}{l}0.5331 \\
0.1801 \\
\end{array}$ & & $\begin{array}{l}0.8107 \\
0.8481 \\
\end{array}$ & & $\begin{array}{l}0.4465 \\
0.8185 \\
\end{array}$ \\
\hline \multirow[t]{2}{*}{4} & $23 / 10 / 13$ & CAAR & -0.7310 & & -1.1238 & & -1.9176 & & 0.2493 & & 0.2873 \\
\hline & $\begin{array}{c}\text { Comprehensive } \\
\text { Assessment }\end{array}$ & $\begin{array}{l}\text { p-value (adjBMP) } \\
\text { p-value (GENSIGN) }\end{array}$ & $\begin{array}{l}0.1491 \\
0.8967 \\
\end{array}$ & & $\begin{array}{l}0.1171 \\
0.3882 \\
\end{array}$ & & $\begin{array}{l}0.0188 \\
0.0053 \\
\end{array}$ & $\begin{array}{l}* * \\
* * * \\
\end{array}$ & $\begin{array}{l}0.5578 \\
0.1574 \\
\end{array}$ & & $\begin{array}{l}0.0514 \\
0.1237 \\
\end{array}$ \\
\hline \multirow[t]{2}{*}{5} & $08 / 11 / 13$ & CAAR & 0.2937 & & 0.5254 & & -0.0090 & & -0.1255 & & -0.2266 \\
\hline & Resolution & $\begin{array}{l}\text { p-value (adjBMP) } \\
\text { p-value (GENSIGN) }\end{array}$ & $\begin{array}{l}0.5992 \\
0.8906 \\
\end{array}$ & & $\begin{array}{l}0.9236 \\
0.6313 \\
\end{array}$ & & $\begin{array}{l}0.9538 \\
0.6016 \\
\end{array}$ & & $\begin{array}{l}0.6788 \\
0.4322 \\
\end{array}$ & & $\begin{array}{l}0.5173 \\
0.7459 \\
\end{array}$ \\
\hline \multirow[t]{2}{*}{6} & $03 / 02 / 14$ & CAAR & -0.1598 & & -0.3109 & & 0.3342 & & 0.0662 & & 0.4643 \\
\hline & $\begin{array}{c}\text { Comprehensive } \\
\text { Assessment }\end{array}$ & $\begin{array}{l}\text { p-value (adjBMP) } \\
\text { p-value (GENSIGN) }\end{array}$ & $\begin{array}{l}0.9710 \\
0.0270 \\
\end{array}$ & $* *$ & $\begin{array}{l}0.8104 \\
0.0566 \\
\end{array}$ & $*$ & $\begin{array}{l}0.5965 \\
0.1615 \\
\end{array}$ & & $\begin{array}{l}0.8272 \\
0.3712 \\
\end{array}$ & & $\begin{array}{l}0.0511 \\
0.1242 \\
\end{array}$ \\
\hline \multirow[t]{2}{*}{7} & $07 / 02 / 14$ & CAAR & 0.1981 & & 0.3014 & & 0.3693 & & -0.0979 & & 0.4242 \\
\hline & Supervision & $\begin{array}{l}\text { p-value (adjBMP) } \\
\text { p-value (GENSIGN) }\end{array}$ & $\begin{array}{l}0.3100 \\
0.8270\end{array}$ & & $\begin{array}{l}0.2389 \\
0.1177\end{array}$ & & $\begin{array}{l}0.3470 \\
0.3136\end{array}$ & & $\begin{array}{l}0.8582 \\
0.0145\end{array}$ & $* *$ & $\begin{array}{l}0.0861 \\
0.3515\end{array}$ \\
\hline \multirow[t]{2}{*}{8} & $11 / 03 / 14$ & CAAR & 0.9008 & & 1.3490 & & 1.1673 & & -0.3538 & & 0.1282 \\
\hline & $\begin{array}{c}\text { Comprehensive } \\
\text { Assessment }\end{array}$ & $\begin{array}{l}\text { p-value (adjBMP) } \\
\text { p-value (GENSIGN) }\end{array}$ & $\begin{array}{l}0.5146 \\
0.6436\end{array}$ & & $\begin{array}{l}0.4758 \\
0.8057\end{array}$ & & $\begin{array}{l}0.4267 \\
0.5110\end{array}$ & & $\begin{array}{l}0.6285 \\
0.8159\end{array}$ & & $\begin{array}{l}0.9543 \\
0.7711 \\
\end{array}$ \\
\hline \multirow[t]{2}{*}{9} & $20 / 03 / 14$ & CAAR & -0.2892 & & -0.1130 & & -0.1787 & & -0.8511 & & 0.3444 \\
\hline & Resolution & $\begin{array}{l}\text { p-value (adjBMP) } \\
\text { p-value (GENSIGN) }\end{array}$ & $\begin{array}{l}0.4278 \\
0.1310 \\
\end{array}$ & & $\begin{array}{l}0.9913 \\
0.4725\end{array}$ & & $\begin{array}{l}0.9531 \\
0.5834 \\
\end{array}$ & & $\begin{array}{l}0.2176 \\
0.0421\end{array}$ & $* *$ & $\begin{array}{l}0.2566 \\
0.1308\end{array}$ \\
\hline \multirow[t]{2}{*}{10} & $25 / 04 / 14$ & CAAR & -0.1318 & & -0.1341 & & -0.1490 & & -0.0871 & & 0.1420 \\
\hline & Supervision & $\begin{array}{l}\text { p-value (adjBMP) } \\
\text { p-value (GENSIGN) }\end{array}$ & $\begin{array}{l}0.8758 \\
0.8200\end{array}$ & & $\begin{array}{l}0.8678 \\
0.9927\end{array}$ & & $\begin{array}{l}0.9864 \\
0.6762 \\
\end{array}$ & & $\begin{array}{l}0.9107 \\
0.4740\end{array}$ & & $\begin{array}{l}0.4817 \\
0.3539 \\
\end{array}$ \\
\hline \multirow[t]{2}{*}{11} & $29 / 04 / 14$ & CAAR & -0.2338 & & -0.4106 & & -0.4551 & & 0.2550 & & -0.3184 \\
\hline & $\begin{array}{c}\text { Comprehensive } \\
\text { Assessment }\end{array}$ & $\begin{array}{l}\text { p-value (adjBMP) } \\
\text { p-value (GENSIGN) }\end{array}$ & $\begin{array}{l}0.3034 \\
0.0478 \\
\end{array}$ & $* *$ & $\begin{array}{l}0.1337 \\
0.0233\end{array}$ & $* *$ & $\begin{array}{l}0.1926 \\
0.0398\end{array}$ & $* *$ & $\begin{array}{l}0.2752 \\
0.8601\end{array}$ & & $\begin{array}{l}0.2341 \\
0.1369 \\
\end{array}$ \\
\hline \multirow[t]{2}{*}{12} & $17 / 07 / 14$ & CAAR & 0.1236 & & 0.1352 & & 0.0863 & & 0.0529 & & -0.0553 \\
\hline & $\begin{array}{c}\text { Comprehensive } \\
\text { Assessment }\end{array}$ & $\begin{array}{l}\text { p-value (adjBMP) } \\
\text { p-value (GENSIGN) }\end{array}$ & $\begin{array}{l}0.4849 \\
0.9081 \\
\end{array}$ & & $\begin{array}{l}0.4894 \\
0.8291 \\
\end{array}$ & & $\begin{array}{l}0.8621 \\
0.7802 \\
\end{array}$ & & $\begin{array}{l}0.9560 \\
0.3854\end{array}$ & & $\begin{array}{l}0.9386 \\
0.4011 \\
\end{array}$ \\
\hline \multirow[t]{2}{*}{13} & $08 / 08 / 14$ & CAAR & -0.2444 & & -0.0556 & & -0.2188 & & -0.6372 & & -0.0058 \\
\hline & $\begin{array}{c}\text { Comprehensive } \\
\text { Assessment }\end{array}$ & $\begin{array}{l}\text { p-value (adjBMP) } \\
\text { p-value (GENSIGN) }\end{array}$ & $\begin{array}{l}0.7832 \\
0.4763\end{array}$ & & $\begin{array}{l}0.3808 \\
0.6018\end{array}$ & & $\begin{array}{l}0.5520 \\
0.9106\end{array}$ & & $\begin{array}{l}0.1588 \\
0.0465\end{array}$ & $* *$ & $\begin{array}{l}0.9622 \\
0.8094\end{array}$ \\
\hline
\end{tabular}




\begin{tabular}{|c|c|c|c|c|c|c|c|c|c|c|}
\hline \multirow[t]{2}{*}{14} & $04 / 09 / 14$ & CAAR & 0.4863 & 0.8745 & & 1.1290 & & -0.5138 & & -0.0323 \\
\hline & $\begin{array}{c}\text { Comprehensive } \\
\text { Assessment }\end{array}$ & $\begin{array}{l}\text { p-value (adjBMP) } \\
\text { p-value (GENSIGN) }\end{array}$ & $\begin{array}{l}0.6419 \\
0.1372 \\
\end{array}$ & $\begin{array}{l}0.1965 \\
0.0005 \\
\end{array}$ & $* * *$ & $\begin{array}{l}0.1767 \\
0.0005 \\
\end{array}$ & $* * *$ & $\begin{array}{l}0.0407 \\
0.0102 \\
\end{array}$ & $\begin{array}{l}* * \\
* * \\
\end{array}$ & $\begin{array}{l}0.9946 \\
0.3803 \\
\end{array}$ \\
\hline \multirow[t]{2}{*}{15} & $27 / 10 / 14$ & CAAR & -0.4742 & -0.9363 & & -1.9292 & & 0.6207 & & 0.2685 \\
\hline & $\begin{array}{c}\text { Comprehensive } \\
\text { Assessment }\end{array}$ & $\begin{array}{l}\text { p-value (adjBMP) } \\
\text { p-value (GENSIGN) }\end{array}$ & $\begin{array}{l}0.4160 \\
0.7756 \\
\end{array}$ & $\begin{array}{l}0.9956 \\
0.5201 \\
\end{array}$ & & $\begin{array}{l}0.5452 \\
0.2955 \\
\end{array}$ & & $\begin{array}{l}0.0898 \\
0.1760 \\
\end{array}$ & $*$ & $\begin{array}{l}0.3225 \\
0.7228 \\
\end{array}$ \\
\hline \multirow[t]{2}{*}{16} & $30 / 10 / 14$ & CAAR & -0.6773 & -1.3210 & & -2.3291 & & 1.0814 & & 0.1846 \\
\hline & Supervision & $\begin{array}{l}\text { p-value (adjBMP) } \\
\text { p-value (GENSIGN) }\end{array}$ & $\begin{array}{l}0.7770 \\
0.9991 \\
\end{array}$ & $\begin{array}{l}0.1659 \\
0.0482 \\
\end{array}$ & $* *$ & $\begin{array}{l}0.0600 \\
0.0071 \\
\end{array}$ & $\begin{array}{c}* \\
* * * \\
\end{array}$ & $\begin{array}{l}0.0001 \\
0.0004 \\
\end{array}$ & $\begin{array}{c}* * \\
* \\
* * \\
* \\
\end{array}$ & $\begin{array}{l}0.6433 \\
0.8020 \\
\end{array}$ \\
\hline \multirow[t]{2}{*}{17} & $04 / 11 / 14$ & CAAR & 0.0927 & 0.0120 & & -0.2813 & & 0.4103 & & -0.0357 \\
\hline & Supervision & $\begin{array}{l}\text { p-value (adjBMP) } \\
\text { p-value (GENSIGN) }\end{array}$ & $\begin{array}{l}0.5457 \\
0.9752 \\
\end{array}$ & $\begin{array}{l}0.2771 \\
0.1782\end{array}$ & & $\begin{array}{l}0.2125 \\
0.0222\end{array}$ & $* *$ & $\begin{array}{l}0.0079 \\
0.0140\end{array}$ & $\begin{array}{c}* * \\
*\end{array}$ & $\begin{array}{l}0.6062 \\
0.3405 \\
\end{array}$ \\
\hline
\end{tabular}

Description: The table reports the CAARs in the stock market (in \%) in response to the key announcement on the BU. It indicates whether the event is related to the supervision, resolution or CA. It shows the CAARs for (i) the entire sample of banks (ALL); (ii) banks located in euro area countries (EU_EZ); (iii) banks located in euro area peripheral countries (GIIPS); (iv) banks located in EU non-euro area countries (EU_NONEZ); and (v) G-SIBs. Significance is tested according to the adjusted version of the Boehmer et al. (1991) test (adjBMP) by Kolari and Pynnönen (2010) and the generalized sign test by Cowan (1992) (GENSIGN). Note: ${ }^{* * *}$ significant at the $1 \%$ level; ${ }^{* *}$ significant at the $5 \%$ level; * significant at the $10 \%$ level. 